NBER WORKING PAPER SERIES

\title{
HOUSEHOLD RISK MANAGEMENT AND \\ OPTIMAL MORTGAGE CHOICE
}

\author{
John Y. Campbell \\ Joao F. Cocco \\ Working Paper 9759 \\ http://www.nber.org/papers/w9759
}

\section{NATIONAL BUREAU OF ECONOMIC RESEARCH 1050 Massachusetts Avenue Cambridge, MA 02138}

June 2003

We would like to thank Deborah Lucas, François Ortalo-Magné, Todd Sinai, Joseph Tracy, three anonymous referees, and the editor, Edward Glaeser, for helpful comments. The views expressed herein are those of the authors and not necessarily those of the National Bureau of Economic Research.

C2003 by John Y. Campbell and Joao F. Cocco. All rights reserved. Short sections of text not to exceed two paragraphs, may be quoted without explicit permission provided that full credit including (C) notice, is given to the source. 
Household Risk Management and Optimal Mortgage Choice

John Y. Campbell and Joao F. Cocco

NBER Working Paper No. 9759

June 2003

JEL No. G1, E4

\begin{abstract}
A typical household has a home mortgage as its most significant financial contract. The form of this contract is correspondingly important. This paper studies the choice between a fixed-rate (FRM) and an adjustable-rate (ARM) mortgage. In an environment with uncertain inflation, a nominal FRM has risky real capital value whereas an ARM has a stable real capital value. However an ARM can increase the short-term variability of required real interest payments. This is a disadvantage of the ARM for a household that faces borrowing constraints and has only a small buffer stock of financial assets. The paper uses numerical methods to solve a life-cycle model with risky labor income and borrowing constraints, under alternative assumptions about available mortgage contracts. While an ARM is generally an attractive form of mortgage, a household with a large mortgage, risky labor income, high risk aversion, a high cost of default, and a low probability of moving is less likely to prefer an ARM. The paper also considers an inflation-indexed FRM, which removes the wealth risk of the nominal FRM without incurring the income risk of the ARM, and is therefore a superior vehicle for household risk management. The welfare gain from mortgage indexation can be very large.
\end{abstract}

John Y. Campbell

Department of Economics

Harvard University

Littauer Center 213

Cambridge, MA 02138

and NBER

john_campbell@harvard.edu

Joao F. Cocco

London Business School

Regent's Park

London NW1 4SA

United Kingdom

jcocco@london.edu 


\section{Introduction}

The portfolio of the typical American household is quite unlike the diversified portfolio of liquid assets discussed in finance textbooks. The major asset in the portfolio is a house, a relatively illiquid asset with an uncertain capital value. The value of the house generally exceeds the net worth of the household, which finances its homeownership through a mortgage contract to create a leveraged position in residential real estate. Other financial assets and liabilities are typically far less important than the house and its associated mortgage contract.

The importance of housing in household wealth is illustrated in Figure 1. This figure plots the fraction of household assets in housing and in equities against the wealth percentile of the household. Poor households appear at the left of the figure and wealthy households at the right. Data come from the 1989 and 1998 Survey of Consumer Finances. The figure shows that middle-class American families (from roughly the 40th to the 80th percentile of the wealth distribution) have more than half their assets in the form of housing. Even after the expansion of equity ownership during the 1990's, equities are of negligible importance for these households. ${ }^{3}$

Academic economists have explored the effects of illiquid risky housing on saving and portfolio choice (see for example Cocco 2001, Davidoff 2002, Flavin and Yamashita 2002, Fratantoni 2001, Goetzmann 1993, Hu 2001, Skinner 1994, and Yao and Zhang 2001). Some have proposed innovative risk-sharing arrangements in which households share ownership of their home with financial institutions (Caplin et al. 1997) or buy insurance against declines in local house price indexes (Shiller 1998, Shiller and Weiss 1999) in order to reduce their exposure to fluctuations in house prices. Such arrangements have not yet been implemented on any significant scale, perhaps because the occupant of a single-family home has inadequate incentives to maintain the home when he is not the sole owner, or because homeownership protects households from fluctuations in local rents (Sinai and Souleles 2003), or because of

\footnotetext{
${ }^{3}$ We are grateful to Joe Tracy for providing us with this figure. The methodology used to construct it is explained in Tracy, Schneider, and Chan (1999) and Tracy and Schneider (2001). Wealth is defined as total assets, without subtracting liabilities and including all assets except human capital and defined-benefit pension plans. Households in the Survey of Consumer Finances are sorted by this measure of wealth, then the median share in real estate and equity is calculated separately for families in each percentile of the wealth distribution. The medians are smoothed across neighboring percentiles in the figure. Equity holdings include direct holdings as well as mutual funds, defined-contribution retirement accounts, trusts, and managed accounts.
} 
barriers to innovation in retail financial markets.

In this paper we consider a household that solely owns a house with an uncertain capital value, financing it with a mortgage. We turn attention to the form of the mortgage contract, which can also have large effects on the risks faced by the homeowner. We view the choice of a mortgage contract as a problem in household risk management, and we conduct a normative analysis of this problem. Our goal is to discover the characteristics of a household that should lead it to prefer one form of mortgage over another. We abstract from all other aspects of household portfolio choice by assuming that household savings are invested entirely in riskless assets.

Mortgage contracts are often complex and differ along many dimensions. But conventional mortgages can be broadly classified into two main categories: adjustablerate $(\mathrm{ARM})$ and nominal fixed-rate $(\mathrm{FRM})$ mortgages. In this paper we study the choice between these two types of mortgages, characterizing the advantages and disadvantages of each type for different households. We compare these conventional mortgages with inflation-indexed fixed-rate mortgages of the sort proposed by Fabozzi and Modigliani (1992), Kearl (1979), Statman (1992) and others.

When deciding on the type of mortgage, an extremely important consideration is labor income and the risk associated with it. Labor income or human capital is undoubtedly a crucial asset for the majority of households. If markets are complete such that labor income can be capitalized and its risk insured, then labor income characteristics play no role in the mortgage decision. In practice, however, markets are seriously incomplete because moral hazard issues prevent investors from borrowing against future labor income, and insurance markets for labor income risk are not well developed.

In this paper we solve a dynamic model of the optimal consumption and mortgage choices of a finitely lived investor who is endowed with non-tradable human capital that produces a risky stream of labor income. The framework is the buffer-stock savings model of Zeldes (1989), Deaton (1991), and Carroll (1997), calibrated to microeconomic data following Cocco, Gomes, and Maenhout (1999) and Gourinchas and Parker (2002). The investor initially buys a house with a required minimum downpayment, financing the rest of the purchase with either an ARM or an FRM. Subsequently the investor can refinance the FRM, if the value of the house exceeds the principal balance of the mortgage, by paying a fixed cost. ${ }^{4}$ We can also allow the

\footnotetext{
${ }^{4}$ The fixed cost represents some combination of explicit "points", often charged at the initiation
} 
investor to take out a second loan, up to the point where total debt equals the value of the house less the required downpayment, and we can allow for a fixed probability each period that the investor will move house. We ask how these options and other parameters of the model affect mortgage choice.

Our results illustrate a basic tradeoff between several types of risk. A nominal FRM, without a prepayment option, is an extremely risky contract because its real capital value is highly sensitive to inflation. The presence of a prepayment option protects the homeowner against one side of this risk, because the homeowner can call the mortgage at face value if nominal interest rates fall, taking out a new mortgage contract with a lower nominal rate. However this option does not come for free; it raises the interest rate on an FRM and leaves the homeowner with a contract that is expensive when inflation is stable, but extremely cheap when inflation increases as occurred during the 1960's and 1970's. This wealth risk is an important disadvantage of a nominal FRM.

An ARM, on the other hand, is a safe contract in the sense that its real capital value is almost unaffected by inflation. The risk of an ARM is the income risk of short-term variability in the real payments that are required each month. If expected inflation and nominal interest rates increase, nominal mortgage payments increase proportionally even though the price level has not yet changed much; thus real monthly payments are highly variable. This variability would not matter if the homeowner could borrow against future income, but it does matter if the homeowner faces binding borrowing constraints. Constraints bind in states of the world with low income and low house prices; in these states buffer-stock savings are exhausted and home equity falls below the minimum required to take out a second loan. The danger of an ARM is that it will require higher interest payments in this situation, forcing a temporary but unpleasant reduction of consumption. We find that households with large houses relative to their income, volatile labor income, or high risk aversion are particularly adversely affected by the income risk of an ARM.

Our model also allows for real interest rate risk, the risk that the cost of borrowing will increase during the life of a long-term loan. Merton (1973) pointed out that longterm investors should be just as concerned about shocks to interest rates as about

of a mortgage contract, and implicit transactions costs (Stanton 1995). We do not allow households to choose among mortgages offering a tradeoff of points against interest rates (Stanton and Wallace 1998). Caplin, Freeman, and Tracy (1997) and Chan (2001) emphasize that refinancing can become impossible if house prices fall below mortgage balances so that homeowners have negative home equity. 
shocks to their wealth; as Campbell and Viceira (2001, 2002) have emphasized, this means that short-term debt is not a safe investment for long-term investors. The same point applies to long-term borrowers. Long-term FRMs protect homeowners against the risk that real interest rates will increase, whereas ARMs do not.

The mobility of a household and its current level of savings also affect the form of the optimal mortgage contract. If a household knows it is highly likely to move in the near future, or if it is currently borrowing-constrained, the most appropriate mortgage is more likely to be the one with the lowest current interest rate. Unconditionally, this is the ARM, since the FRM rate incorporates a positive term premium and the cost of the FRM prepayment option; but if the short-term interest rate is currently high and likely to fall, the FRM might have a lower rate. Thus our model implies that homeowners should respond to the yield spread between FRM and ARM mortgage rates, which is driven by the yield spread between long-term and short-term bond yields. When this yield spread is unusually high, more homeowners should take out ARMs; when it is unusually low, more homeowners should take out FRMs.

One solution to the risk management problems identified in this paper is an inflation-indexed FRM. This contract removes the wealth risk of the nominal FRM without incurring the income and real interest rate risks of the standard ARM contract. The inflation-indexed FRM should also have a lower mortgage rate than a nominal FRM, since the real term structure is flatter than the nominal term structure and the option to prepay an inflation-indexed mortgage is less valuable. We calibrate our model to US interest data over the period 1962-1999 and find large welfare gains from indexation of FRMs. These results parallel the findings of Campbell and Shiller (1996) and Campbell and Viceira (2001) that inflation-indexed bonds should be attractive to conservative long-term investors.

It is interesting to compare our normative results with historical patterns in mortgage financing, and with the advice that homeowners receive from books on personal finance. The United States is unusual among industrialized countries in that the predominant mortgage contract is a long-term nominal FRM, usually with a 30-year maturity. The monthly interest rate survey of the Federal Housing Finance Board shows that long-term nominal FRMs accounted for $70 \%$ of newly issued mortgages on average during the period 1985-2001, while ARMs accounted for $30 \%$. Nominal FRMs have a very large secondary market, whose liquidity has been supported by US government policy over many decades, particularly through the government agency GNMA (Government National Mortgage Association or "Ginnie Mae"), and 
the private but government-sponsored entities FNMA (Federal National Mortgage Association or "Fannie Mae") and FHLMC (Federal Home Loan Mortgage Corporation or "Freddie Mac"). The liquidity of this market likely reduces the rates on nominal FRMs and helps to account for their popularity in the United States. ${ }^{5}$

Figure 2 plots the evolution of the FRM share over time. The FRM share is strongly negatively correlated with the level of long-term interest rates (the correlation with the 10-year Treasury yield is -0.77 in levels and -0.57 in quarterly changes). Accordingly the FRM share trended upward during the period 1985-2001 as interest rates trended downward; it averaged around $60 \%$ in the late 1980's and around $80 \%$ in the late 1990's. Surprisingly the FRM share is almost uncorrelated with the yield spread between 10-year and 1-year interest rates (the correlation is 0.10 in levels and 0.02 in quarterly changes) ${ }^{6}$

One explanation for the tendency of households to use FRMs when long-term interest rates have recently fallen is that households believe long-term interest rates to be mean-reverting. If declines in long-term interest rates tend to be followed by increases, then it is rational to "lock in" a long-term interest rate that is low relative to past history by taking out a FRM. Some personal finance books offer advice of this sort. Irwin (1996), for example, offers the following tip: "When interest rates are low, get a fixed-rate mortgage and lock in the low rate" (p.143), while Steinmetz (2002) advises "If you think rates are going up, get a fixed-rate mortgage" (p.84). The difficulty with this advice, of course, is that movements in long rates are extremely difficult to forecast. The expectations theory of the term structure implies that changes in long-term bond yields should be almost unforecastable; while there is some empirical evidence against this theory (see for example Campbell and Shiller (1991) or Campbell, Lo, and MacKinlay (1997, Chapter 10)), it seems overambitious for the average homeowner to try to predict movements in long-term interest rates.

\footnotetext{
${ }^{5}$ Woodward (2001) describes in detail how federal policy has supported the FRM market. Several studies have found important liquidity effects in mortgage markets. Cotterman and Pearce (1996) find a 25-40 basis point spread between private label mortgages and the conforming mortgages that are securitized by FNMA and FHLMC, while Black, Garbade, and Silber (1981) and Rothberg, Nothaft, and Gabriel (1989) find that the initial securitization of mortgages by GNMA lowered mortgage interest rates by $60-80$ basis points.

${ }^{6}$ During 2002, the FRM share fell even while interest rates declined. This attracted the attention of the business press as a departure from the historical pattern. See for example Ruth Simon, "Do You Have the Wrong Mortgage? In Puzzling Move, Homeowners Flock to Riskier Variable Loans Instead of Locking In Low Rates", Wall Street Journal, June 18, 2002.
} 
Other recommendations of personal finance books are more consistent with the normative results presented in this paper. Homeowners who expect to move within a few years are often advised to take out ARMs to exploit the low initial interest rate. Tyson and Brown (2000), for example, write: "Many homebuyers don't expect to stay in their current homes for a long time. If that's your expectation, consider an ARM. Why? Because an ARM starts at a lower interest rate than does a fixed-rate loan, you should save interest dollars in the first two years of holding your ARM." (p.64). ARMs are also recommended for homeowners who are currently borrowing constrained but expect their incomes to grow rapidly: "ARMs are best utilized... when your cash flow is currently tight but you expect it to increase as time goes on" (Orman 1999, p.254); "Sometimes ARMs have lower initial loan costs. If cash is a big consideration for you, look into them" (Irwin 1996, p.144).

Personal finance books do not explicitly distinguish different types of risk as we do in this paper. However some personal finance authors clearly think that income risk and real interest rate risk are important for homeowners, because they describe ARMs as risky assets and FRMs as safe: "An ARM can pay off, but it's a gamble. Sometimes there's a lot to be said for something that's safe and dependable, like a fixed-rate mortgage." (Fisher and Shelly 2002, p. 319).

There is a large academic literature on mortgage choice. Follain (1990) surveys the literature from the 1980's and earlier. Much recent work focuses on FRM prepayment behavior, and its implications for the pricing of mortgage-backed securities (for example Schwartz and Torous 1989 and Stanton 1995). One strand of the literature emphasizes that households know more about their moving probabilities than lenders do; this creates an adverse selection problem in prepayment that can be mitigated through the use of fixed charges or "points" at mortgage initiation (Dunn and Spatt 1985, Chari and Jagannathan 1989, Brueckner 1994, LeRoy 1996, Stanton and Wallace 1998).

A few papers discuss the choice between adjustable-rate and fixed-rate mortgages. On the theoretical side, Alm and Follain (1984) emphasize the importance of labor income and borrowing constraints for mortgage choice, but their model is deterministic and thus they cannot address the risk management issues that are the subject of this paper. Stanton and Wallace (1999) discuss the interest-rate risk of ARMs, but without considering the role of risky labor income and borrowing constraints. We are not aware of any previous theoretical work that treats income risk and interest-rate risk within an integrated framework as we do here. On the empirical side, Shilling, 
Dhillon, and Sirmans (1987) look at micro data on mortgage borrowing and estimate a reduced-form econometric model of mortgage choice. They find that households with a more stable income and households with a higher moving probability are more likely to use ARMs. These findings are consistent both with our theoretical model and with the typical advice given by books on personal finance.

The organization of the paper is as follows. Section 2.1 lays out the model of household choice, and section 2.2 calibrates its parameters. Section 3 compares alternative nominal mortgage contracts, while section 4 studies inflation-indexed FRMs. Section 5 asks whether our results are robust to alternative parameterizations. Section 6 concludes. 


\section{A Life-Cycle Model of Mortgage Choice}

\subsection{Model specification}

Time parameters and preferences

We model the consumption and asset choices of a household, indexed by $j$, with a time horizon of $T$ periods. We study the decision of how to finance the purchase of a house of a given size $\bar{H}_{j}$. That is, we assume that buying a house is strictly preferred to renting - perhaps because of tax considerations - so that we do not model the decision to buy versus rent. In addition, we do not study what determines the initial choice of house size, and we assume that the household remains in a house of this size, regardless of the path of household income. Thus we ignore the possibility that the household can adjust to an income shock by moving to a larger or smaller house. ${ }^{7}$

In each period $t, t=1, \ldots, T$, the household chooses real consumption of all goods other than housing, $C_{j t}$. We assume preference separability between housing and consumption. Since the size of the house and the utility derived from it are fixed, we can omit housing from the objective function of the household and write:

$$
\max E_{0} \sum_{t=0}^{T} \beta^{t} \frac{C_{j t}^{1-\gamma}}{1-\gamma}+\beta^{T+1} \frac{W_{j, T+1}^{1-\gamma}}{1-\gamma}
$$

where $\beta$ is the time discount factor and $\gamma$ is the coefficient of relative risk aversion. The household derives utility from terminal real wealth, $W_{j, T+1}$, which can be interpreted as the remaining lifetime utility from reaching age $T+1$ with wealth $W_{j, T+1}$.

The term structure of nominal and real interest rates

FRM and ARM mortgages differ because nominal interest rates are variable over time. This variability comes from movements in both the expected inflation rate and

\footnotetext{
${ }^{7}$ Cocco (2001) studies the choice of house size using a life-cycle model similar to the one in this paper. Sinai and Souleles (2003) study the choice between renting and buying housing.
} 
the ex ante real interest rate. We use the simplest model that captures variability in both these components of the short-term nominal interest rate, and allows for some predictability of interest rate movements. Thus in our model there will be periods when homeowners can rationally anticipate declining or increasing short-term nominal interest rates, and thus declining or increasing ARM payments.

We write the nominal price level at time $t$ as $P_{t}$. We adopt the convention that lower-case letters denote $\log$ variables, thus $p_{t}=\log \left(P_{t}\right)$ and the log inflation rate $\pi_{t}=p_{t+1}-p_{t}$. To simplify the model, we abstract from one-period uncertainty in realized inflation; thus expected inflation at time $t$ is the same as inflation realized from $t$ to $t+1$. While clearly counterfactual, this assumption should have little effect on our comparison of nominal mortgage contracts, since short-term inflation uncertainty is quite modest and affects nominal ARMs and FRMs symmetrically. Later in the paper we consider inflation-indexed mortgages; the absence of one-period inflation uncertainty in our model will lead us to understate the advantages of these mortgages.

We assume that expected inflation follows an $\mathrm{AR}(1)$ process. That is,

$$
\pi_{t}=\mu(1-\phi)+\phi \pi_{t-1}+\epsilon_{t}
$$

where $\epsilon_{t}$ is a normally distributed white noise shock with mean zero and variance $\sigma_{\epsilon}^{2}$. By contrast, we assume that the ex ante real interest rate is variable but serially uncorrelated. The expected log real return on a one-period bond, $r_{1 t}=\log \left(1+R_{1 t}\right)$, is given by:

$$
r_{1 t}=\bar{r}+\psi_{t}
$$

where $\bar{r}$ is the mean log real interest rate and $\psi_{t}$ is a normally distributed white noise shock with mean zero and variance $\sigma_{\psi}^{2}$.

We make the assumption that real interest rate risk is transitory for tractability. Fama (1975) showed that the assumption of a constant real interest rate was a good approximation for US data in the 1950's and 1960's, but it is well known that more recent US data display serially correlated movements in real interest rates (see for example Garcia and Perron 1996, Gray 1996, or Campbell and Viceira 2001). However movements in expected inflation are the most important influence on long-term 
nominal interest rates (Fama 1990, Mishkin 1990, Campbell and Ammer 1993), and our $\mathrm{AR}(1)$ assumption for expected inflation allows persistent variation in nominal interest rates.

The $\log$ nominal yield on a one-period nominal bond, $y_{1 t}=\log \left(1+Y_{1 t}\right)$, is equal to the log real return on a one-period bond plus expected inflation:

$$
y_{1 t}=r_{1 t}+\pi_{t} .
$$

To model long-term nominal interest rates, we assume that the log expectations hypothesis holds. That is, we assume that the log yield on a long-term $n$-period nominal bond, $y_{n t}=\log \left(1+Y_{n t}\right)$, is equal to the expected sum of successive log yields on one-period nominal bonds which are rolled over for $n$ periods plus a constant term premium, $\xi$ :

$$
y_{n t}=(1 / n) \sum_{i=0}^{n-1} E_{t}\left[y_{1, t+i}\right]+\xi .
$$

This model implies that excess returns on long-term bonds over short-term bonds are unpredictable, even though changes in nominal short rates are partially predictable. Thus there are no predictably good or bad times to alter the maturity of a bond portfolio, and homeowners cannot reduce their average borrowing costs by trying to time the bond market.

\section{Available mortgage contracts}

At date one, household $j$ finances the purchase of a house of size $\bar{H}_{j}$ with a nominal loan of $(1-\lambda) P_{j 1}^{H} \bar{H}$, where $\lambda$ is the required down-payment and $P_{j 1}^{H}$ is the date one nominal price of the house. The mortgage loan is assumed to have maturity $T$, so that it is paid off by period $T+1$.

If the household chooses a nominal FRM, and the date one interest rate on a FRM with maturity $T$ is $Y_{T 1}^{F}$, then in each subsequent period the household must make a real mortgage payment, $M_{j t}^{F}$, of: 


$$
M_{j t}^{F}=\frac{(1-\lambda) P_{j 1}^{H} \bar{H}_{j}}{P_{t} \sum_{j=1}^{T}\left(1+Y_{T 1}^{F}\right)^{-j}} .
$$

Since nominal mortgage payments are fixed at mortgage initiation, real payments are inversely proportional to the price level $P_{t}$. This implies that a nominal FRM, without a prepayment option, is a risky contract because its real capital value is highly sensitive to inflation.

We allow for a prepayment option. A household that chooses an FRM may in later periods refinance at a monetary cost of $\rho$. Let $I_{j t}^{\rho}$ be an indicator variable which takes the value of one if the household refinances in period $t$, and zero otherwise. We assume that a refinancing household at date $t$ obtains a new FRM mortgage with the same principal as the remaining principal of the old mortgage, and with maturity $T-t+1$ such that by the terminal date $T+1$ the mortgage will have been paid down. We allow refinancing to occur regardless of the level of house prices at time $t$, as would be the case with an automatically refinancing mortgage; thus we do not impose a constraint that the refinancing household's home equity must exceed the minimum downpayment.

We assume that the date $t$ nominal interest rate on a FRM is given by:

$$
Y_{T-t+1, t}^{F}=Y_{T-t+1, t}+\theta^{F},
$$

where $\theta^{F}$ is a constant mortgage premium over the yield on a $(T-t+1)$-period bond. This premium compensates the mortgage lender for default risk and for the value of the refinancing option.

If the household chooses an ARM, the annual real mortgage payment, $M_{j t}^{A}$, is given by the following. We write $D_{j t}$ for the nominal principal amount of the original loan outstanding at date $t$. Then the date $t$ real mortgage payment is given by:

$$
M_{t}^{A}=\frac{Y_{1 t}^{A} D_{j t}+\Delta D_{j, t+1}}{P_{t}},
$$

where $\Delta D_{j, t+1}$ is the component of the mortgage payment at date $t$ that goes to pay down principal rather than pay interest. We assume that $\Delta D_{j, t+1}$ is equal to the average nominal loan reduction that occurs at date $t$ in a FRM for the same initial 
loan. While this does not correspond exactly to a conventional ARM, it greatly simplifies the problem since by having loan reductions that depend only on time and the amount borrowed, the proportion of the original loan that has been repaid is not a state variable.

The date $t$ nominal interest rate on an ARM is assumed to be equal to the short rate plus a constant premium:

$$
Y_{1 t}^{A}=Y_{1 t}+\theta^{A}
$$

The ARM mortgage premium $\theta^{A}$ compensates the mortgage lender for default risk.

\section{Labor income risk}

The household is endowed with stochastic gross real labor income in each period, $L_{j t}$, which cannot be traded or used as collateral for a loan. As usual we use a lower case letter to denote the natural log of the variable, so $l_{j t} \equiv \log \left(L_{j t}\right)$. Household $j$ 's log real labor income is exogenous and is given by:

$$
l_{j t}=f\left(t, Z_{j t}\right)+v_{j t}+\omega_{j t}
$$

where $f\left(t, Z_{j t}\right)$ is a deterministic function of age $t$ and other individual characteristics $Z_{j t}$, and $v_{j t}$ and $\omega_{j t}$ are stochastic components of income. Thus log income is the sum of a deterministic component that can be calibrated to capture the hump shape of earnings over the life-cycle, and two random components, one transitory and one persistent. The transitory component is captured by the shock $\omega_{j t}$, an i.i.d. normally distributed random variable with mean zero and variance $\sigma_{\omega}^{2}$. The persistent component is assumed to be entirely permanent; it is captured by the process $v_{j t}$, which is assumed to follow a random walk:

$$
v_{j t}=v_{j, t-1}+\eta_{j t},
$$

where $\eta_{j t}$ is an i.i.d. normally distributed random variable with mean zero and variance $\sigma_{\eta}^{2}$. These assumptions closely follow Cocco, Gomes, and Maenhout (1999) and other papers on the buffer-stock model of savings. 
We allow transitory labor income shocks, $\omega_{j t}$, to be correlated with innovations to the stochastic process for expected inflation, $\epsilon_{t}$, and denote the corresponding coefficient of correlation $\varphi$. To the extent that wages are set in real terms, this correlation is likely to be zero. If wages are set in nominal terms, however, the correlation between real labor income and inflation may be negative, and this can affect the form of the optimal mortgage contract.

\section{Taxation}

We model the tax code in the simplest possible way, by considering a linear taxation rule. Gross labor income, $L_{t}$, is taxed at the constant tax rate $\tau$. We also allow for mortgage interest deductibility at this rate.

\section{House prices and second loans}

The price of housing fluctuates over time. Let $p_{j t}^{H}$ denote the date $t$ real log price of house $j$. Real house price growth is given by

$$
\Delta p_{j t}^{H}=g+\delta_{j t}
$$

a constant $g$ plus an i.i.d. normally distributed shock $\delta_{j t}$ with mean zero and variance $\sigma_{\delta}^{2}$. To economize on state variables we assume that innovations to a household's real house price are perfectly positively correlated with innovations to the permanent component of the household's real labor income so that

$$
\delta_{j t}=\alpha \eta_{j t}
$$

where $\alpha>0$. This assumption implies that states with low house prices are also states with low permanent labor income; in these states an increase in required mortgage payments under an ARM contract can require costly adjustments in consumption. In the next section we use PSID data to judge the plausibility of this assumption. ${ }^{8}$

\footnotetext{
${ }^{8} \mathrm{~A}$ large positive correlation between income shocks and house prices is also present in OrtaloMagné and Rady (2001).
} 
House prices matter in our model because we impose the realistic constraint, emphasized by Caplin, Freeman, and Tracy (1997) and Chan (2001), that refinancing of a FRM is only possible if the value of the house, less the minimum downpayment, exceeds the principal balance of the mortgage. In addition, we can extend the model to allow households to obtain a second one-period loan to bring total debt up to the value of the house less the minimum downpayment. Recall that $D_{j t}$ is the nominal dollar amount of the original loan outstanding at date $t$. We allow households at time $t$ to borrow $B_{j t}$ nominal dollars for one period subject to the constraint

$$
B_{j t} \leq(1-\lambda) P_{j t}^{H} \overline{H_{j}}-D_{j t} .
$$

That is, total borrowing cannot exceed the original proportion of house value that could be borrowed at date one. We assume that the nominal interest rate on the second loan is equal to $Y_{1 t}$ plus a constant premium, $\theta^{B}$.

\section{Household default}

In each period the household decides whether or not to default on the loan. In case of default the bank seizes the house and the household is forced into the rental market for the remainder of its life. We set the rental cost equal to the user cost of housing plus a constant rental premium, $\theta^{R}$. The real rental cost $Z_{t}$ for a house of size $\bar{H}$ with price $P_{t}^{H}$ is given by:

$$
Z_{t}=\frac{\left[Y_{1 t}-E_{t}\left(\Delta p_{t+1}^{H}+\pi_{t+1}\right)+\theta^{R}\right] P_{t}^{H} \bar{H}}{P_{t}},
$$

where $Y_{1, t}$ is the one-period nominal interest rate, $E_{t}\left(\Delta p_{t+1}^{H}+\pi_{1, t+1}\right)$ is the expected proportional nominal change in the house price, and $P_{t}^{H} \bar{H}$ is the date $t$ value of the house. The rental premium covers the moral hazard problem of renting, that tenants have no incentive to look after a property so that maintenance becomes more expensive. In addition, and contrary to interest payments on a mortgage loan, the rental cost of housing is not tax-deductible, which increases the after-tax cost of renting. 


\section{Bank profits}

The date $t$ real profit of lenders of funds, or banks, depends on whether there is default. For an ARM loan to a household with no second loan it is given by:

$$
\Pi_{j t}=\frac{\left(P_{t}^{H} \bar{H}-D_{j t}\right) I_{j t}^{Z}+\theta^{A} D_{j t}\left(1-I_{j t}^{Z}\right)}{P_{t}},
$$

where $I_{t}^{Z}$ is an indicator variable which takes the value of one if the household defaults in period $t$ and zero otherwise (of course this variable is not defined in case there has been default in a period prior to $t$ ). In case of default the bank seizes the house but loses the outstanding mortgage principal. If there is no default the bank receives the ARM premium on the outstanding loan. For a FRM the household can also refinance the loan, in which case interest payments cease but the bank receives the outstanding mortgage principal.

\section{Moving}

We introduce moving in the model in the following simple manner: with probability $p$ the household moves in each period. When this happens the household sells the house, pays off the remaining mortgage, and evaluates utility of wealth using the terminal utility function. This enables us to study the impact of the likelihood of moving, or of termination of the mortgage contract, on mortgage choice.

\section{Summary of the household's optimization problem}

In summary, the household's control variables are $\left(C_{j t}, B_{j t}, I_{j t}^{\rho}, I_{j t}^{Z}\right)$ at each date $t$. The problem is somewhat simpler in the case of an ARM, because in this case the refinancing indicator variable $I_{j t}^{\rho}$ is not a control variable. The vector of state variables can be written as $X_{j t}=\left(t, y_{1 t}, W_{j t}, P_{t}, y_{1, t_{j}^{\prime}}, t_{j}^{\prime}, v_{j t}, S_{j t}^{Z}\right)$ at each date $t$, where $y_{1, t_{j}^{\prime}}\left(t_{j}^{\prime}<t\right)$ is the level of nominal interest rates when the mortgage was initiated or was last refinanced, $t_{j}^{\prime}$ is the period when the mortgage was initiated or was last refinanced, $W_{j t}$ is real liquid wealth or cash-on-hand, $P_{t}$ is the date $t$ price level, $v_{j t}$ 
is the household's permanent labor income, and $S_{j t}^{Z}$ is a state variable that takes the value of one if there has been previous default and zero otherwise.

The equation describing the evolution of real cash-on-hand for an ARM when there has not been previous default, and with no second loan, can be written as

$$
W_{j, t+1}=\left(W_{j t}-C_{j t}-M_{j t}^{A}+\tau Y_{1 t}^{A} D_{j t} / P_{t}\right)\left(1+R_{1, t+1}\right)+(1-\tau) L_{j, t+1}
$$

or when there has been previous default

$$
W_{j, t+1}=\left(W_{j t}-C_{j t}-Z_{j t}\right)\left(1+R_{1, t+1}\right)+(1-\tau) L_{j, t+1}
$$

and similarly for a FRM.

\section{Solution technique}

This problem cannot be solved analytically. Given the finite nature of the problem a solution exists and can be obtained by backward induction. We discretize the state space and the choice variables using equally spaced grids in the log scale. The density functions for the random variables were approximated using Gaussian quadrature methods to perform numerical integration (Tauchen and Hussey 1991). The nominal interest rate process was approximated by a two-state transition probability matrix. The grid points for these processes were chosen using Gaussian quadrature. In period $T+1$ the utility function coincides with the value function. In every period $t$ prior to $T+1$, and for each admissible combination of the state variables, we compute the value associated with each combination of the choice variables. This value is equal to current utility plus the expected discounted continuation value. To compute this continuation value for points which do not lie on the grid we use cubic spline interpolation. The combinations of the choice variables ruled out by the constraints of the problem are given a very large (negative) utility such that they are never optimal. We optimize over the different choices using grid search. 


\subsection{Parameterization}

We study the optimal consumption and mortgage choices of investors who buy a house early in life. Adult age in our model starts at age 26 and we let $T$ be equal to 30 years. For computational tractability, we let each period in our model correspond to two years but we report annualized parameters and data moments for ease of interpretation. In the baseline case we assume an annual discount factor $\beta$ equal to 0.98 and a coefficient of relative risk aversion $\gamma$ equal to three. We will study how the degree of risk aversion affects mortgage choice.

\section{Inflation and interest rates}

Parameter estimates for inflation and interest rates are reported in Table 1. Our measure of inflation is the consumer price index. We use annual data from 1962 to 1999, time aggregated to two-year periods, to estimate equation (2). We find average inflation of $4.6 \%$ per year, with a standard deviation of $3.9 \%$, and an annual autoregressive coefficient of 0.754 . To measure the log real interest rate we deflate the two-year nominal interest rate using the consumer price index. We measure the variability of the ex-ante real interest rate by regressing ex post two-year real returns on lagged two-year real returns and two-year nominal interest rates, and then calculating the variability of the fitted value. We obtain a standard deviation of $2.2 \%$ per year, as compared with a mean of $2.0 \%$. This standard deviation is surprisingly high, which may be a result of overfitting in our regression; but since our assumption that all real interest rate risk is transitory artificially diminishes the importance of such risk, we use this high standard deviation to partially offset this effect. Our results are not particularly sensitive to changes in the volatility of the real interest rate.

In order to assess how well our model for the term structure matches the data we have computed the annualized standard deviations of the two-year bond yield, the ten-year bond yield, and the spread between them. The values we obtain are $5.3 \%$, $1.9 \%$, and $3.5 \%$, respectively. The corresponding values in the data are $3.1 \%, 2.9 \%$, and $0.7 \%$. It appears that our model overstates the volatility of the short rate and understates its persistence, which means that we understate the volatility of the long rate level and overstate the volatility of the long-short yield spread.

In section 5, on alternative parameterizations we assess the benefits of mortgage 
indexation when we calibrate our interest-rate process to a process characteristic of the US in the 1983-1999 period. As expected, the estimated parameters (reported in section 5) imply considerably lower inflation risk in this period.

\section{Mortgage contracts, second loans and rental premium}

Two important parameters of the mortgage contracts are the mortgage premiums, $\theta^{F}$ and $\theta^{A}$. It is natural to assume that $\theta^{F} \geq \theta^{A}$. One can think of $\theta^{A}$ as a pure measure of default risk, while $\theta^{F}$ contains both default risk and the value of the prepayment option.

To estimate the mortgage premiums on the contracts we use data from the monthly interest rate survey of the Federal Housing Finance Board (FHFB) from January 1986 to December 2001. To estimate the mortgage premium on FRM contracts, $\theta^{F}$, we compute the difference between interest rates on commitments for fixed-rate mortgages and the yield to maturity on 10-year treasury bonds. The average annual difference over this period is $1.8 \%$.

To estimate the mortgage premium on ARM contracts, $\theta^{A}$, we compute the difference between the ARM contract rate and the yield on a 1-year bond over the same sample period. The average annual difference is equal to $1.7 \%$. This number may be biased downwards by the fact that ARMs sometimes have low initial "teaser" rates to lure households into the ARM commitment.

The difference between the ARM and FRM premiums is surprisingly small. This may result in part from measurement error in the survey data or the short sample period of the survey. It may also result from the liquidity of the FRM market which has been supported by US government policy over many decades, particularly through the activities of GNMA and the government's sponsorship of FNMA and FHLMC.

We set the term premium equal to $1.0 \%$, the average yield spread between 10-year and 1-year Treasury bonds over the period 1986-2001. This term premium increases the average interest cost of FRMs relative to ARMs.

We assume a required downpayment of $20 \%$, and we set the rental premium $\theta^{Z}$ to $3.0 \%$. In the baseline case we make $\theta^{B}$ infinite and therefore do not allow the homeowner to take out a second loan. We relax this restriction in section 5 . 


\section{House prices}

We use house price data from the PSID for the years 1970 through 1992. As with income the self assessed value of the house was deflated using the Consumer Price Index, with 1992 as the base year, to obtain real house prices. We drop observations for households who reported that they moved in the previous two years since the house price reported does not correspond to the same house. In order to deal with measurement error we drop the observations in the top and bottom five percent of real house price changes.

We estimate the average real growth rate of house prices and the standard deviation of innovations to this growth rate. Over the sample period real house prices grew an average of $1.6 \%$ per year. Part of this increase is due to improvements in the quality of houses, which cannot be separated from other reasons for house price appreciation using PSID data. The annualized standard deviation of house price changes is $11.5 \%$, a value comparable to those reported by Case and Shiller (1989) and Poterba (1991).

We consider two alternative house sizes. In the benchmark case the household purchases a house costing $\$ 187,500$ using a $\$ 150,000$ mortgage and paying $\$ 37,500$ down. (The downpayment is assumed to come from prior savings or transfers from family members, rather than from current income.) In an alternative case, the household purchases a smaller house costing $\$ 125,000$ using a $\$ 100,000$ mortgage and a $\$ 25,000$ downpayment.

\section{Labor income}

To estimate the income process, we follow Cocco, Gomes, and Maenhout (1999). We use the family questionnaire of the Panel Study on Income Dynamics (PSID) to estimate labor income as a function of age and other characteristics. In order to obtain a random sample, we drop families that are part of the Survey of Economic Opportunities subsample. Only households with a male head are used, as the age profile of income may differ across male- and female-headed households, and relatively few observations are available for female-headed households. Retirees, nonrespondents, students, and homemakers are also eliminated from the sample.

Like Cocco, Gomes, and Maenhout (1999) and Storesletten, Telmer, and Yaron 
(2003), we use a broad definition of labor income so as to implicitly allow for insurance mechanisms - other than asset accumulation - that households use to protect themselves against pure labor income risk. Labor income is defined as total reported labor income plus unemployment compensation, workers compensation, social security, supplemental social security, other welfare, child support and total transfers (mainly help from relatives), all this for both head of household and if present his spouse. Observations which still reported zero for this broad income category were dropped.

Labor income defined this way is deflated using the Consumer Price Index, with 1992 as the base year. The estimation controls for family-specific fixed effects. The function $f\left(t, Z_{j t}\right)$ is assumed to be additively separable in $t$ and $Z_{j t}$. The vector $Z_{j t}$ of personal characteristics, other than age and the fixed household effect, includes marital status, household composition, and the education of the head of the household. ${ }^{9}$ Figure 3 shows the fit of a third order polynomial to the estimated age dummies for singles and married couples with a high school education but no college degree. We use these age profiles for our calibration exercise. Average annual income for married couples is about $40 \%$ higher than income for singles, starting at around $\$ 23,000$ and peaking at $\$ 32,000$. This means that a house of given size is larger relative to income if it is owned by a single person.

The residuals obtained from the fixed-effects regressions of log labor income on $f\left(t, Z_{j t}\right)$ can be used to estimate $\sigma_{\eta}^{2}$ and $\sigma_{\omega}^{2}$. Define $l_{j t}^{*}$ as:

$$
l_{j t}^{*} \equiv l_{j t}-f\left(t, Z_{j t}\right)
$$

Equation (10) implies that

$$
l_{j t}^{*}=v_{j t}+\omega_{j t}
$$

Taking first differences:

\footnotetext{
${ }^{9}$ Campbell, Cocco, Gomes, and Maenhout (2001) estimate separate age profiles for different educational groups. They also estimate different income processes for households whose heads are employed in different industries, or self-employed. In this version of the paper, we focus on a single representative income process for simplicity.
} 


$$
l_{j t}^{*}-l_{j, t-1}^{*}=v_{j t}-v_{j, t-1}+\omega_{j t}-\omega_{j, t-1}=\eta_{j t}+\omega_{j t}-\omega_{j, t-1} .
$$

We consider several alternative methods for calibrating the standard deviations of the permanent and transitory shocks to income. One approach is to use the standard deviation of income innovations from (21), and the correlation between innovations to income and real house price growth, to obtain estimates for the standard deviations of $\eta_{j t}$ and $\omega_{j t}$. The estimated correlation is 0.027 , with a p-value of $2 \%$. Recall that in the model, and for tractability, we have assumed that real house price growth is perfectly positively correlated with innovations to the persistent component of income, and has zero correlation with purely transitory shocks. This assumption, and the standard deviation of $\eta_{j t}+\omega_{j t}-\omega_{j, t-1}$, imply that $\sigma_{\eta}$ and $\sigma_{\omega}$ are $0.35 \%$ and $16.3 \%$ respectively. This estimate of $\sigma_{\eta}$, the standard deviation of permanent income shocks, seems too low. The reason is probably that measurement error biases our estimate of the correlation between house price and income growth downwards.

An alternative approach is to use household level data on income growth over several periods to estimate $\sigma_{\eta}$ and $\sigma_{\omega}$. Following Carroll (1992) and Carroll and Samwick (1997), Cocco, Gomes, and Maenhout (1999) estimate that $\sigma_{\eta}$ and $\sigma_{\omega}$ are $10.3 \%$ and $27.2 \%$ respectively. Storesletten, Telmer, and Yaron (2003) have reported similar numbers. ${ }^{10}$

These numbers may be somewhat inflated by measurement error in the PSID. A large standard deviation for permanent income growth is particularly problematic for our model of mortgage choice because we assume a house of a fixed size and ignore the possibility that the household will choose to move to a larger or smaller house. This implies for example that our model will tend to overpredict default rates when permanent income is volatile.

To avoid this difficulty we use a third calibration approach. We assume that all shocks to permanent labor income are aggregate shocks, so that idiosyncratic income risk is purely transitory. This assumption is consistent with the fact that aggregate labor income appears close to a random walk (Fama and Schwert 1977, Jagannathan and Wang 1996). In this case $\sigma_{\eta}$ can be estimated as in Cocco, Gomes, and Maenhout (1999) by averaging across all individuals in our sample and taking the

\footnotetext{
${ }^{10}$ There is a large literature in empirical labor economics that estimates similar parameters, sometimes allowing them to vary over time. See for example Abowd and Card (1989), Gottschalk and Moffitt (1994), or MaCurdy (1982).
} 
standard deviation of the growth rate of average income. Following this procedure we estimate $\sigma_{\eta}$ equal to $2.0 \%$. For our baseline case we set $\sigma_{\omega}$ equal to $14.1 \%$ ( $20 \%$ over two years), which implies a correlation of house price growth with total income growth of about 0.1. Given the somewhat arbitrary nature of these decisions, we are careful to do sensitivity analysis with respect to the income growth parameters. We consider a higher transitory standard deviation of $24.8 \%$ (35\% over two years) in the tables reported below, and in addition we have recomputed some results for a higher permanent standard deviation of $5 \%$ with similar results to those reported.

In the baseline case we set the correlation between transitory labor income shocks and innovations to expected inflation, $\varphi$, equal to zero.

\section{Taxation}

The PSID contains information on total estimated federal income taxes of the household. We use this variable to obtain an estimate of $\tau$. Dividing total federal taxes by our broad measure of labor income and computing the average across households, we obtain an average tax rate of $10.3 \%$. This number underestimates the effect of taxation because the PSID does not contain information on state taxes, and because our model abstracts from the progressivity of the income tax. To roughly compensate for these biases we set $\tau$ equal to $20 \%$. All the calibrated parameters are summarized in Table 1. 


\section{Alternative Nominal Mortgages}

We now use our model to compare fixed and adjustable rate nominal mortgages. We do so by calculating optimal consumption and refinancing plans, and the associated lifetime expected utilities, under alternative FRM and ARM contracts. We are particularly interested in the effects of house size, income risk, and the level of income on behavior and welfare. Accordingly we consider two alternative house sizes - $\$ 125,000$ and $\$ 187,500$, corresponding to mortgages of $\$ 100,000$ and $\$ 150,000$, respectivelytwo levels of transitory income risk - annual standard deviations of 0.141 and 0.248 and two income levels - calibrated for a couple and a single person.

One way to get a sense for the size of these mortgages in relation to income is to calculate the ratio of total mortgage payments to income, both in the first year of the mortgage and averaged over the life of the mortgage. We have done this for the ARM, averaging across different levels of interest rates. For a couple, the payment on a $\$ 100,000$ mortgage amounts to $36 \%$ of income in the first year and $16 \%$ of income on average over the life of the mortgage, while the payment on a $\$ 150,000$ mortgage is $53 \%$ of income initially and $24 \%$ of income on average. For a single, these mortgages are more burdensome. A $\$ 100,000$ mortgage costs $50 \%$ of income initially and $22 \%$ on average, while a $\$ 150,000$ mortgage is an extreme case that costs $75 \%$ of income initially and $33 \%$ on average.

As a first step towards a welfare analysis, Figure 4 plots the distribution of realized lifetime utility, based on simulation of the model across one thousand households. Each household is assumed to have to finance a $\$ 150,000$ mortgage on a $\$ 187,500$ home using either an ARM, or an FRM with a $\$ 1,000$ refinancing cost. In the top panel of the figure the household has a couple's income, while in the bottom panel the household has a smaller single person's income. In both cases the lower standard deviation of income growth, 0.141 , is assumed.

Figure 4 shows that ARMs have substantial advantages for most households. For couples, an ARM delivers higher utility everywhere in the utility distribution. For singles, with lower income relative to house size, households in the upper part of the utility distribution are better off with an ARM, but a few households at the lower end of the distribution are substantially worse off. These results reflect the chief disadvantage of an ARM, the cash-flow risk that ARM payments will rise suddenly, exhausting bufferstock savings and forcing an unpleasant cutback in consumption. This risk is important when the mortgage is large relative to income. 


\section{Default}

The cash-flow risk in ARM payments also implies that the proportion of households who choose to default on each loan tends to be higher under an ARM than under a FRM. Default rates are extremely low for couples, but Figure 5 plots cumulative default rates for singles with low income risk (dashed lines) and high income risk (solid lines) respectively. It is important to note that these default rates are obtained from simulating the behavior of households who differ in their history of shocks to interest rates, labor income and house prices. Households choose to default when faced with negative labor income shocks, so that bufferstock savings become low, and with negative house price shocks, so that home equity becomes negative. In a simulation scenario in which house prices and labor income shocks are mainly positive (negative) default rates are lower (higher). Figure 5 shows cumulative default over the life cycle. Since the risk in mortgage payments is higher early in life when buffer-stock savings are smaller, default occurs mainly within the first eight years of the contract.

There are some differences in the circumstances that trigger default under each mortgage contract. While low labor income and house prices trigger default for both types of contract, households with ARMs choose to default when current interest rates and therefore current mortgage payments are high. They do so because default allows them to avoid paying down the principal of their mortgage, and this reduction in payments is particularly valuable when interest rates are high. Households with FRMs, on the other hand, choose to default when current interest rates are low and expected to rise. In these circumstances borrowing constraints are more severe under the FRM contract than in the rental market, because the FRM mortgage payment is based on the long-term interest rate while the rental payment is based on the current short-term interest rate.

\section{Refinancing}

Figure 5 also shows the cumulative refinancing of FRMs by singles with low income risk. The refinancing rate is slightly higher for singles with high income risk, and for couples, because these households accumulate larger savings and thus are more readily able to afford the $\$ 1,000$ refinancing cost. Over the life of the mortgage, about $45 \%$ of households refinance their mortgages; almost all of this refinancing activity takes place within the first 20 years of the mortgage, since late refinancing reduces interest payments on a smaller principal balance for fewer years but incurs the same 
fixed cost as early refinancing. The timing of refinancing is somewhat sensitive to the constraint we have imposed, that homeowners must have positive home equity in order to refinance. If we relax this constraint we get higher refinancing in the very early years of the mortgage, but the difference diminishes over time and is only about $1 \%$ after 12 years. This reflects the fact that house prices increase on average, while outstanding mortgage principal diminishes, so that very few households are likely to have persistently negative home equity.

\section{Consumption behavior}

Table 2 reports the average consumption growth rate and the standard deviation of consumption growth for households with ARMs, nominal FRMs that allow refinancing, and nominal FRMs without a refinancing option. The top panel of the table is for a couple, while the bottom panel is for a single. Within each panel, we consider a small or large house, and low or high income risk. Average consumption growth rates are very similar for all mortgages, since they depend largely on the hump-shaped profile of labor income in the presence of borrowing constraints. In one case with a large house relative to income the average consumption growth rate is higher for an ARM, reflecting precautionary savings to guard against the cash-flow risk of the ARM. The form of the mortgage has a larger effect on the volatility of consumption growth. Volatility is lowest with an ARM, higher with a refinancing FRM, and highest with a non-refinanceable FRM. These numbers reflect the dominance of wealth risk over income risk in determining consumption volatility over the life cycle.

\section{Welfare analysis}

Table 3 summarizes the welfare implications of these numbers. The table reports the welfare provided by a FRM, with or without a refinancing option, relative to an ARM. We calculate welfare using a standard consumption-equivalent methodology. For each mortgage contract we compute the constant consumption stream that makes the household as well off in expected utility terms, and then measure the change in this equivalent consumption stream across mortgage contracts. In all the cases we consider, the ARM is the best available mortgage contract. The welfare consequences of this can be very large, reflecting the importance of the mortgage decision in the financial life of a household. If we consider a couple with low income risk and a large $\$ 187,500$ house as a benchmark case, the couple is $5.96 \%$ worse off with a nominal 
FRM that allows cheap refinancing, and $6.79 \%$ worse off with a FRM that prohibits refinancing.

The welfare advantage of the ARM diminishes when the house is large relative to income and when income is volatile. In the extreme case of a single with high income risk and a large house, the household is only $1.03 \%$ worse off with a refinanceable FRM than with an ARM. This reflects the fact that the cash-flow risk of an ARM is disproportionately more important when labor income is risky and the house is large relative to income.

By comparing welfare levels across FRMs with alternative refinancing costs, we can obtain the value of the option to refinance. In the benchmark case this option is worth $0.83 \%$ of consumption; it becomes more valuable when the house is large relative to income, and when income is risky. Note that these numbers assume a fixed FRM rate even while changing the cost of refinancing, and thus they do not impose a zero-profit condition on mortgage lenders.

All the numbers in Table 3 are averages across states of the world with high and low interest rates. We have also calculated expected utility conditional on an initial interest rate. As one would expect, the ARM is even more advantageous if the interest rate is initially low, since in this case the ARM has a lower cost in the early years when borrowing constraints are most severe. The FRM is more attractive if the interest rate is initially high; in the benchmark case a couple will slightly prefer an ARM even with a high initial interest rate, but a single will strongly prefer a FRM. Thus our model implies that households' financing decisions should be sensitive to the slope of the term structure. As we discussed in the introduction, the time-series behavior of US mortgage financing does not match this prediction. However our ability to explore this issue is limited by the fact that our discretized model allows only two possible levels of interest rates.

\section{Bank profits}

Using (16) we have calculated the average annual profit of lenders of funds under each mortgage contract, assuming that the bank borrows funds at the one-period riskless interest rate. In the benchmark case of a couple with low income risk and a large house, the average annual profit is $\$ 745$ for the ARM and $\$ 1218$ for a refinanceable FRM. The higher average profit on the FRM comes from the term premium that banks earn by borrowing short and lending long; of course, this term premium 
can be regarded as compensation for the risk that banks take when they mismatch the maturity of their borrowing and lending. 


\section{Inflation-Indexed Mortgages}

In this section we investigate the welfare properties of inflation-indexed mortgages. In principle an inflation-indexed FRM can offer the wealth stability of an ARM, together with the income stability of an FRM; it should therefore be a superior vehicle for household risk management.

We consider inflation-indexed FRM contracts in which the interest rate is fixed in real terms. We study the welfare properties of a standard inflation-indexed FRM contract, with constant real mortgage payments, and also those of an inflation-indexed mortgage whose real payments diminish at the average rate of inflation. We do so because our investor is borrowing constrained; one of the advantages of the standard inflation-indexed FRM contract, relative to the nominal FRM and ARM contracts, is that real payments are lower early in life, when borrowing constraints are more severe. This advantage of the standard inflation-indexed contract is conceptually distinct from the risksharing advantage of indexation. Thus, to obtain a pure measure of the risksharing advantage of indexation we consider an inflation-indexed mortgage whose real payments diminish at the average rate of inflation.

\section{Inflation-indexed mortgage terms}

If in period one household $j$ chooses an inflation-indexed FRM with fixed real payments, and the current real interest rate on an inflation-indexed FRM contract with maturity $T$ is $R_{T 1}^{I}$, then in each subsequent period the household must make a real mortgage payment, $M_{j t}^{I}$, of:

$$
M_{j t}^{I}=\frac{(1-\lambda) P_{j 1}^{H} \overline{H_{j}}}{\sum_{j=1}^{T}\left(1+R_{T, 1}^{I}\right)^{-j}} .
$$

Real mortgage payments are fixed at mortgage initiation, and nominal payments increase in proportion to the price level $P_{t}$. Thus, unlike a nominal FRM, the real capital value of an inflation-indexed mortgage is not sensitive to inflation.

For the inflation-indexed mortgage contract we ignore the possibility of refinancing. Given our assumption that real interest rate variation is transitory, the gains from refinancing in our model would be fairly small, and even a small monetary refinancing cost would prevent households from exercising their option. In reality, even 
with persistent real interest rates, the possibility of refinancing an inflation-indexed contract is likely to be only a minor feature of the contract, given the low volatility of the real interest rate compared with that of nominal yields.

We assume that the date $t$ real interest rate on an inflation-indexed FRM is given by:

$$
R_{T-t+1, t}^{I}=R_{T-t+1, t}+\theta^{I}
$$

where $\theta^{I}$ is a constant mortgage premium over the yield on a $(T-t+1)$-period real bond, $R_{T-t+1, t}$, which is determined by the expectations theory of the term structure applied to log real interest rates. We assume that there is no log term premium for long-term real bonds, that is, that the real term structure is flat on average. This is consistent with the observed behavior of real yields on Treasury inflationprotected securities since their issue in 1997 (Roll 2003). Since we do not allow for the possibility of refinancing the inflation-indexed FRM contract we set $\theta^{I}$ equal to the ARM premium of $1.7 \%$. This premium compensates the mortgage lender for the initiation cost of the mortgage and for default risk.

In the inflation-indexed mortgage with real payments which diminish at the average rate of inflation we have that:

$$
M_{j t}^{D}=\frac{M_{j, t-1}^{D}}{1+\mu}
$$

where $M_{t}^{D}$ is the date $t$ real mortgage payment and $\mu$ is average inflation. The interest rate or internal rate of return for this mortgage contract is assumed to be equal to that for the standard inflation-indexed FRM.

Consumption behavior, default, and bank profits

The standard inflation-indexed mortgage with constant real payments eases the household's borrowing constraints. The real payments under this contract are lower than the required real payments on nominal mortgages early in life, when borrowing constraints are more severe. A measure of the degree to which investors are borrowing constrained is consumption growth. Table 4 shows that in the benchmark case the average consumption growth rate under the inflation-indexed contract with constant 
real payments is only $0.8 \%$ compared to $2.0 \%$ with an ARM or a nominal FRM. Because the inflation-indexed mortgage allows households to remain in debt later in life, it increases the effect of income risk on consumption; thus the standard deviation of consumption growth is actually higher with this contract than with an ARM.

The inflation-indexed mortgage with declining real payments has a much smaller effect on average consumption growth. There is some reduction in the average consumption growth rate for households with high income risk and large houses, reflecting the fact that known real mortgage payments require smaller bufferstocks and generate less precautionary saving than the random real payments required by ARMs. The major effect of an inflation-indexed mortgage with declining real payments is to reduce the volatility of consumption growth, since this mortgage eliminates both the wealth risk of the nominal FRM and the income risk of the ARM.

The inflation-indexed FRM also reduces default risk. For the parameter values we have considered, households with inflation-indexed mortgages never default. Average annual profits of lenders are $\$ 1081$ for the standard inflation-indexed mortgage, and $\$ 971$ for the mortgage with declining real payments. These profits are higher than those for the ARM. In equilibrium these lower default rates and higher profits might be translated into lower inflation-indexed mortgage premiums, which would further benefit households.

\section{Welfare analysis}

Figure 4 plots the distribution of realized lifetime utility for households with inflation-indexed FRMs with constant or declining real payments. The figure shows that the welfare gains of inflation-indexed mortgages are substantial for both couples and singles. The gains are particularly large for households at the bottom of the welfare distribution, but there are benefits to households across the distribution. The inflation-indexed mortgage with constant real payments is always superior to the mortgage with declining real payments.

Table 5 shows the average welfare gains of the inflation-indexed mortgages relative to the ARM in the form of standard consumption-equivalent variations. For ease of reference the earlier comparison of the nominal FRM with the ARM is repeated here. In the benchmark case of a couple with a $\$ 187,500$ house and low income risk, the inflation-indexed mortgage with constant real payments offers a welfare gain over an ARM equivalent to $3.95 \%$ of consumption. The welfare gain increases with house 
size and with income risk, since ARMs are particularly problematic with large houses and risky income. In the extreme case of a single with a large house and high income risk, the welfare gain of inflation indexation exceeds $36 \%$ of consumption.

Comparing the two inflation-indexed contracts, we see that the average welfare gains of the contract with declining real mortgage payments are considerably smaller than those of the mortgage contract with fixed real payments, but they remain positive in every case we consider. In the benchmark case Table 5 shows that households are on average $0.91 \%$ better off with a declining inflation-indexed FRM than with an ARM. Again the welfare gains increase dramatically with house size and income risk.

These results imply that with substantial inflation risk of the sort we have estimated for the 1962-1999 period, the risksharing advantages of indexation are very large. Households would be able to manage their lifetime risks much more effectively if they had access to inflation-indexed mortgage contracts. Of course, these results depend on the parameters we have estimated. In the next section we assess the benefits of mortgage indexation for alternative parameterizations, including an income process in which nominal wages are temporarily sticky, and an interest-rate process characteristic of the US in the recent period of declining inflation. 


\section{Alternative Parameterizations}

Sticky nominal wages

When nominal wages are inflation-indexed, or equivalently when wages are fixed in real terms, the correlation between real labor income shocks and inflation shocks is zero. We have assumed this in our benchmark parameterization. However, in a world where implicit contracts tend to fix nominal, but not real wages, the correlation between inflation shocks and real labor income shocks is negative. In such a world households may demand nominal mortgage contracts because their wage contracts are nominal. To explore this coordination feature of nominal contracts we compute the welfare benefits of inflation-indexed mortgages when nominal wages are sticky.

Table 6 repeats the welfare comparison of nominal and inflation-indexed FRMs with ARMs for several alternative specifications. We consider the benchmark case of a couple with a large $\$ 187,500$ house and low income risk. The first row of the table repeats the numbers from Table 5 for this case. The second row shows the average welfare gains of nominal and inflation-indexed FRMs for a negative correlation coefficient of -1 between temporary real labor income shocks and inflation innovations. In the presence of negative correlation, a nominal ARM becomes much less attractive because positive inflation shocks drive up nominal interest rates and increase mortgage payments at times when real labor income is temporarily low. A nominal FRM becomes relatively more attractive, although for the benchmark case reported in Table 6 it does not dominate the ARM.

Negative correlation makes an inflation-indexed mortgage less attractive relative to a nominal FRM. The welfare difference between the inflation-indexed FRM with declining real payments and the nominal FRM is $6.87 \%$ in the benchmark case with a zero correlation, but only $4.68 \%$ with a correlation of -1 . However the inflationindexed mortgage becomes more attractive relative to the ARM, which is particularly disfavored by nominal wage stickiness.

While these results are qualitatively unsurprising, it is striking that temporary nominal wage stickiness does not reverse the welfare ordering we found in the previous section, that inflation-indexed FRMs dominate ARMs, which in turn dominate nominal FRMs. To reverse that ordering we would need to assume nominal stickiness in the permanent component of labor income, which would imply that inflation 
shocks permanently reduce real labor income. Such an assumption is much more extreme than the temporary nominal stickiness we consider here.

\section{The Volcker-Greenspan monetary policy period}

Clarida, Gali, and Gertler (2000) and Campbell and Viceira (2001) report considerably lower inflation risk during the period since 1983 in which Federal Reserve Chairmen Paul Volcker and Alan Greenspan have brought US inflation under control. We now assess the benefits of mortgage indexation when we calibrate our interest-rate process to a process characteristic of the US in the 1983-1999 period. For this period we find lower average inflation (3.4\% as compared with $4.6 \%$ ), less volatile inflation (a standard deviation of $1.2 \%$ as compared with $3.9 \%$ ), less persistent inflation (an autoregressive parameter of 0.41 as compared with 0.75 ), a higher average real interest rate $(3.1 \%$ as compared with $2.0 \%$ ), and a less volatile real interest rate (a standard deviation of $1.6 \%$ as compared with $2.2 \%$ ).

The third row of Table 6 changes the interest-rate parameters to those we calibrate for the 1983-1999 period. The first column shows that nominal FRMs are less attractive relative to ARMs than was the case in our benchmark model. Evidently the stabilization of inflation and interest rates has reduced the income risk of ARMs relatively more than the wealth risk of FRMs. The second and third columns show that inflation-indexed FRMs remain superior mortgage contracts, but the welfare gain is extremely small for the inflation-indexed FRM with declining real payments. It appears that the Volcker-Greenspan monetary policy has reduced the pure risk management advantages of inflation-indexed bonds to a low level.

\section{Second loans}

We now study how allowing homeowners to take out second loans, if they have positive home equity, affects the benefits of mortgage indexation. The fourth row of Table 6 shows the welfare gains for a second loan premium, $\theta^{B}$, of $1 \%$ in annual terms. For tractability, in this case we eliminate the prepayment option on the nominal FRM. We see that the benefits of constant real payments are smaller when second loans are allowed, since these loans are an alternative way to relax the household's borrowing constraints. However second loans do not entirely eliminate the income risk of ARMs, because low house prices may coincide with low income and high inflation, in which 
case second loans are unavailable precisely when they would be most valuable. Thus our basic results survive the addition of second loans to our model.

\section{Moving probability}

We have also solved our model assuming a moving probability equal to 0.10, meaning that the household moves on average once every ten years. Recall that in all the cases reported in earlier tables, the probability of moving is equal to zero. We find that the welfare gain of an ARM over a nominal FRM is higher when the moving probability is higher. If a homeowner knows he is highly likely to move in the near future, he is more likely to use the kind of mortgage that has the lower current interest rate. On average, this is the ARM or the inflation-indexed FRM since the nominal FRM has a higher yield spread that reflects the slope of the nominal term structure.

\section{Consumption in default}

Our results are sensitive to the assumption that we make about consumption in the event of a mortgage default. In the model we assume that in case of default the bank seizes the house and the household is forced into the rental market for the remainder of its life. We set the rental premium equal to the user cost of housing plus a constant rental premium, $\theta^{R}$, which in the benchmark parameterization is equal to $3 \%$. The sixth and seventh rows of Table 6 consider lower and a higher values for the rental premium of $2 \%$ and $4 \%$ respectively. We interpret these as roughly capturing the effects of different default costs or exemption levels in the event of personal bankruptcy. From Table 6 we see that cheaper default makes a nominal FRM less attractive relative to an ARM, because it mitigates the income risk of the ARM. The benefits of FRM indexation are also reduced but remain substantial. Naturally, the cheaper is default the higher is the default rate.

These results suggest that in states or countries where bankruptcy is relatively cheaper one should observe, ceteris paribus, a higher proportion of households choos-

ing ARMs. However we do not adjust the ARM premium $\theta^{A}$ to compensate lenders for variations in the default rate caused by variations in the rental premium, and thus our results do not capture the full general equilibrium effect of the bankruptcy code. 


\section{Impatient and risk-averse households}

In the eighth row of Table 6 we consider impatient investors with a higher time discount rate and a correspondingly smaller time discount factor of 0.90. Such investors accumulate a smaller buffer-stock of liquid financial assets, so they default more often and are more affected by the wealth risk of nominal FRMs and the income risk of ARMs. They gain more from inflation-indexation, even if real payments decline over time. They particularly benefit from the postponed payments of an inflation-indexed FRM with constant real payments.

In the ninth row of the table, we increase the risk aversion coefficient from 3 to 5 . This causes households to become more concerned about the income risk of ARMs. The welfare advantage of ARMs over nominal FRMs diminishes, and the benefits of inflation-indexation increase. Much of the gain from inflation-indexation comes from improved risk management, but these households also have a strong preference for smooth consumption so they benefit from declining real mortgage payments.

\section{Higher standard deviation of persistent income shocks}

The tenth row of Table 6 shows the results for a higher standard deviation of permanent income shocks equal to $5 \%$. The results are qualitatively similar to those for the benchmark case. The main quantitative difference is a reduced benefit of an inflation-indexed mortgage with constant real payments. This change is explained by the fact that with risky permanent income, the option to default becomes more valuable for the ARM and nominal FRM contracts relative to the inflation-indexed mortgage with constant real payments. Once again we do not adjust the ARM or FRM premium for variations in default caused by the change in the volatility of income, and thus our results reflect only a partial equilibrium, not a general equilibrium analysis.

\section{ARM cap and floor}

In the eleventh row of Table 6 we consider a hybrid ARM in which there is a cap of $2 \%$ on the annual increase in the interest rate, and a lifetime cap of $6 \%$ on the

cumulative interest rate increase after mortgage initiation. These terms are fairly 
standard ones for a hybrid ARM. The hybrid ARM is more attractive than either a straight ARM or a nominal FRM, as it mitigates income risk while still limiting wealth risk. The benefits of mortgage indexation are smaller in comparison to a hybrid ARM, and shrink to 7 basis points for an inflation-indexed mortgage with declining real payments.

In practice, ARMs often have more complicated terms including a low initial teaser rate. A teaser rate enables an ARM to capture some of the benefits of an inflationindexed mortgage with constant real payments, but we do not attempt to capture the full richness of available ARM contracts here.

\section{Correlation of income and interest rates}

Our benchmark model assumes that shocks to income growth are uncorrelated with shocks to real interest rates. If we assume instead that income growth is negatively correlated with real interest rates, this exacerbates the income risk of ARMs, since income will tend to be low precisely when interest rates are high and required ARM mortgage payments are high. The twelfth row of Table 6 shows that with a correlation of -0.2 between income and real interest rates, nominal and inflation-indexed FRMs become slightly more attractive relative to ARMs.

\section{Term premium in the real term structure}

The last row of Table 6 assumes that the term premium $\xi$ of $1 \%$ applies to the real term structure as well as the nominal term structure. In this case the spread between long-term nominal and real interest rates is caused only by expected inflation and does

not include an inflation risk premium. This increases the cost of an inflation-indexed mortgage relative to a nominal mortgage, and reduces the benefit of indexation. Under this assumption an ARM looks attractive as a way for a homeowner to avoid paying the term premium.

\section{Refinancing from an ARM to a FRM}

Finally, we consider an alternative specification in which we allow households who choose a nominal ARM to subsequently refinance into a nominal FRM. Recall 
that our baseline specification compares a nominal ARM to a nominal FRM, without allowing households to switch between the two. In practice, and even though there are transaction costs associated with switching between different types of mortgages, it is possible to do so. The complexity of our model prevents us from considering a period-by-period decision to switch mortgages. However, we can study the welfare effects of allowing a one time switch from a nominal ARM to a nominal FRM. It may be the case that ARM borrowers find it optimal to choose the ARM when interest rates are low, but plan to switch to a FRM if and when interest rates increase.

The solution to this alternative specification requires that at each date $t$ and for each combination of the state variables, we compare the utility of remaining an ARM borrower to the utility of switching to the FRM contract. More precisely, let $V_{t}\left(X_{t} ; F R M\right)$ denote the lifetime utility of becoming an FRM borrower at date $t$, when the vector of state variables is given by $X_{t}$. Assuming a zero switching cost, the household will at date $t$ switch to the FRM if and only if $V_{t}\left(X_{t} ; F R M\right)>V_{t}\left(X_{t} ; A R M\right)$, where $V_{t}\left(X_{t} ; A R M\right)$ is the lifetime utility of remaining an ARM borrower with the option to switch to the FRM in a subsequent period.

To solve for the optimal mortgage choices under this alternative specification, we set the parameters equal to their benchmark values and the switching cost to zero. For these parameters most borrowers prefer an ARM and never switch to a FRM. There are $1.3 \%$ of households who start off with an ARM and later on switch to a FRM when current interest rates are high. However, not all households find it optimal to switch to the FRM when current rates are high; only those with low current income and financial wealth do so. The intuition for this result is simple: when current interest rates are high the ARM implies a larger current mortgage payment than the FRM. Those consumers who are more borrowing constrained find it optimal to pay the higher average premium on the FRM in exchange for the lower current mortgage payments. This result illustrates once more the importance of borrowing constraints for mortgage choice. As consumers grow older the labor income profile becomes flatter and households become less borrowing constrained. For this reason the benefits of switching to the FRM contract are lower. This explains our finding that for the baseline parameters all the switching from the ARM to the FRM takes place before age 38 .

We also study the welfare effects of allowing consumers to switch from the ARM to the FRM. We compute the mean welfare gain delivered by the ARM with the option to switch to the FRM, relative to the baseline nominal ARM contract. We 
find a modest welfare gain of $0.27 \%$, reflecting the small number of households that choose to make this switch. 


\section{Conclusion}

The problem of mortgage choice is both basic and complex. It is basic because almost every middle-class American faces this choice at least once in his or her life. It is complex because it involves many considerations that are at the frontier of finance theory: uncertainty in inflation and interest rates, borrowing constraints, illiquid assets, uninsurable risk in labor income, and the need to plan over a long horizon.

Despite the complexity of the problem, it is important for financial economists to try to offer scientifically grounded advice. If financial economists avoid the topic, homeowners may be guided by unwise commercial or journalistic advice; for example they may be urged to time the bond market by predicting the direction of long-term interest rates. Mortgage choice should not be left to specialists in real estate, but should be treated as an aspect of household risk management, a topic that lies at the heart of finance.

In this paper we have shown that the form of the mortgage contract can have large effects on household welfare. We begin by comparing pure forms of the standard nominal ARM and FRM contracts. FRM contracts expose households to wealth risk, while ARM contracts expose them to income risk: the risk that borrowing constraints will bind more severely when high interest rates coincide with low income and house prices. While the exact levels of welfare depend on the particular premia we have assumed for ARM and FRM mortgages, we can draw general conclusions about the types of households that should be more likely to use ARMs. Households with smaller houses relative to income, more stable income, lower risk aversion, more lenient treatment in bankruptcy, and a higher probability of moving should be the households that find ARMs most attractive.

Interestingly, these results match quite well with empirical evidence reported by Shilling, Dhillon, and Sirmans (1987). These authors look at micro data on mortgage borrowing and estimate a reduced-form econometric model of mortgage choice. They find that households with co-borrowers and married couples (whose household income is presumably more stable) and households with a higher moving probability are more likely to use ARMs.

We have also investigated the welfare properties of innovative inflation-indexed mortgage contracts. An inflation-indexed FRM can offer the wealth stability of an ARM together with the income stability of an FRM, so it is a superior vehicle for 
household risk management. Using US data from the period 1962-1999 we find very large welfare gains from the availability of an inflation-indexed mortgage contract. Some of these gains arise from the reduced mortgage payments early in the life of the mortgage that are implied by a constant real payment as opposed to a constant nominal payment. Even if we remove this advantage by requiring real payments that decline at the expected rate of inflation, we still find substantial welfare gains from indexation.

This finding raises the question of why inflation-indexed mortgages are not more commonly used. There are several possible answers to this question. First, the yield spreads between inflation-indexed Treasury securities and nominal Treasury securities have been extremely low, generally below $2 \%$, since inflation-indexed Treasury securities were introduced in 1997 (Roll 2003). This suggests that investors have a high degree of confidence that inflation will remain low in the future, and that the inflation risk premium is low. When we calibrate our interest-rate model to the period since 1983 in which inflation has been relatively well controlled, or when we assume a zero inflation risk premium, we find smaller risk management benefits of indexation. Second, we find that hybrid ARMs with nominal interest rate caps can improve significantly over pure ARMs. These ARMs reduce the benefits of inflationindexation.

Third, inflation-indexed mortgages can cause the outstanding principal of the mortgage to increase over time in nominal terms (although not in real terms). Financial advisers frequently warn against such "negative amortization", without making any distinction between real and nominal debt. Irwin (1996), for example, writes "Another trap has to do with negative amortization. Some of the adjustable loans keep the monthly payments down by adding the interest to the principal. In other words, you end up owing more than you borrowed!" Even more colorfully, Tyson and Brown (2000) write "Negative amortization has the potential to be a personal financial neutron bomb. It destroys the borrower without harming the property. If you're offered an ARM with negative amortization, emphatically say NO!"'11 Suspicion of negative amortization may have inhibited acceptance of innovative mortgage contracts that might reduce the income risk of standard ARMs.

Although our model captures many of the important factors that should influence

\footnotetext{
${ }^{11}$ Steinmetz (2002) offers a more nuanced view, stating that "Negative amortization is not inherently bad". However he, like the other authors quoted here, does not try to distinguish the real value of a debt from its nominal value.
} 
mortgage choice, it remains oversimplified in several important respects. First, we have assumed that households remain in a house of fixed size unless they are randomly forced to move, in which case we evaluate their welfare using a terminal utility function. Second, related to this we assume a relatively low volatility of permanent income growth in order to avoid large mismatches between household income and house size. Third, our model is too stylized to capture teaser rates and other special features of many mortgages that are offered in the marketplace. Fourth, we work in partial equilibrium and do not attempt to use zero-profit conditions for mortgage lenders to solve for equilibrium mortgage premia. We believe there is room for further research to model these issues in a more satisfactory manner.

We have calibrated our model to match basic features of the US mortgage market. Other countries have mortgage markets that differ in important respects. For example, long-term nominal fixed-rate mortgages are almost unknown in the UK and Canada. An interesting area for future research will be to relate these international differences in prevailing mortgage contracts to differences in the risk management problem that households face.

The concept of income risk that we emphasize in this paper has interesting implications for other areas of finance. Corporations, for example, must consider the risk that short-term or floating-rate debt will require high interest payments in circumstances where internal cash flow and collateral are low and external financing is expensive. Here as in the problem of mortgage choice, borrowing constraints both complicate and enrich standard models of risk management. 


\section{References}

Abowd, J. and Card, D., 1989, "On the Covariance Structure of Earnings and Hours Changes," Econometrica 57, 411-445.

Alm, J. and Follain, J. R., 1984, "Alternative Mortgage Instruments, the Tilt Problem and Consumer Welfare," Journal of Financial and Quantitative Analysis $19,113-126$.

Black, Deborah G., Kenneth D. Garbade, and William L. Silber, 1981, "The Impact of the GNMA Pass-Through Program on FHA Mortgage Costs", Journal of Finance 36, 457-469.

Brueckner, J. , 1993, "Why Do We Have ARMs," American Real Estate and Urban Economic Associations Journal 21, 333-345.

Brueckner, J., 1994, "Borrower Mobility, Adverse Selection and Mortgage Points," Journal of Financial Intermediation 3, 416-441.

Brueckner, J., and J.R. Follain, 1988, "The Rise and Fall of the ARM: An Econometric Analysis of Mortgage Choice," Review of Economics and Statistics 70, 93-102.

Campbell, John Y. and John Ammer, 1993, "What Moves the Stock and Bond Markets? A Variance Decomposition for Long-Term Asset Returns", Journal of Finance 48, 3-37.

Campbell, John Y., Andrew W. Lo, and A. Craig MacKinlay, 1997, The Econometrics of Financial Markets, Princeton University Press, Princeton, NJ.

Campbell, John Y. and Robert J. Shiller, 1991, "Yield Spreads and Interest Rate Movements: A Bird's Eye View", Review of Economic Studies 58, 495-514.

Campbell, John Y. and Robert J. Shiller, 1996, "A Scorecard for Indexed Government Debt", in Ben S. Bernanke and Julio J. Rotemberg eds. NBER Macroeconomics Annual 1996, 155-197, MIT Press, Cambridge, MA.

Campbell, John Y. and Luis M. Viceira, 2001, "Who Should Buy Long-Term Bonds?", American Economic Review 91, 99-127. 
Campbell, John Y. and Luis M. Viceira, 2002, Strategic Asset Allocation: Portfolio Choice for Long-Term Investors, Oxford University Press, Oxford.

Caplin, Andrew S., Sewin Chan, Charles Freeman, and Joseph Tracy, 1997, Housing Partnerships: A New Approach to a Market at a Crossroads, MIT Press, Cambridge, MA.

Caplin, Andrew S., Charles Freeman, and Joseph Tracy, 1997, "Collateral Damage: Refinancing Constraints and Regional Recessions", Journal of Money, Credit, and Banking 29, 496-516.

Carroll, Christopher D., 1992, "The Buffer-Stock Theory of Saving: Some Macroeconomic Evidence", Brookings Papers on Economic Activity, 61-156.

Carroll, Christopher D., 1997, "Buffer-Stock Saving and the Life-Cycle/Permanent Income Hypothesis", Quarterly Journal of Economics 114, 433-495.

Carroll, Christopher D. and Andrew A. Samwick, 1997, "The Nature of Precautionary Wealth", Journal of Monetary Economics 40, 41-71.

Case, Karl E. and Robert J. Shiller, 1989, "The Efficiency of the Market for SingleFamily Homes," American Economic Review, 79, 125-137.

Chan, Sewin, 2001, "Spatial Lock-in: Do Falling House Prices Constrain Residential Mobility?", Journal of Urban Economics 49, 567-586.

Chari, V.V. and Ravi Jagannathan, 1989, "Adverse Selection in a Model of Real Estate Lending," Journal of Finance 44, 499-508.

Clarida, Richard, Jordi Gali, and Mark Gertler, 2000, "Monetary Policy Rules and Macroeconomic Stability: Evidence and Some Theory", Quarterly Journal of Economics 115, 147-180.

Cocco, João F., 2001, "Portfolio Choice in the Presence of Housing", unpublished paper, London Business School.

Cocco, João F., Francisco J. Gomes, and Pascal J. Maenhout, 1999, "Consumption and Portfolio Choice over the Life-Cycle", unpublished paper, London Business School and Harvard University. 
Cotterman, Robert F. and James E. Pearce, 1996, "The Effects of the Federal National Mortgage Association and the Federal Home Loan Mortgage Corporation on Conventional Fixed-Rate Mortgage Yields", in Studies on Privatizing Fannie Mae and Freddie Mac, U.S. Department of Housing and Urban Development, Office of Policy Development and Research.

Davidoff, Thomas, 2002, "Labor Income, Housing Prices, and Homeownership", unpublished paper, Haas School of Business, UC Berkeley.

Deaton, Angus S., 1991, "Savings and Liquidity Constraints," Econometrica 59, 1221-1248.

Dunn, Kenneth B. and Chester S. Spatt, 1985, "An Analysis of Mortgage Contracting: Prepayment Penalties and the Due-on-Sale Clause," Journal of Finance 40, 293-308.

Fabozzi, Frank J. and Franco Modigliani, 1992, Mortgage and Mortgage-Backed Securities Markets, Harvard Business School Press, Boston, MA.

Fama, Eugene F., 1975, "Short-Term Interest Rates as Predictors of Inflation", American Economic Review 65, 269-282.

Fama, Eugene F., 1990, "Term Structure Forecasts of Interest Rates, Inflation, and Real Returns", Journal of Monetary Economics 25, 59-76.

Fisher, Sarah and Susan Shelly, 2002, The Complete Idiot's Guide to Personal Finance in Your 20's and 30's, 2nd ed., Alpha Books, Indianapolis, IN.

Flavin, Marjorie and Takashi Yamashita, 2002, "Owner-Occupied Housing and the Composition of the Household Portfolio", American Economic Review 92, 345362.

Follain, J. R., 1990, "Mortgage Choice," American Real Estate and Urban Economic Associations Journal 18, 125-144.

Fratantoni, Michael C., 2001, "Homeownership, Committed Expenditure Risk, and the Stockholding Puzzle", Oxford Economic Papers 53, 241-259.

Garcia, René and Pierre Perron, 1996, "An Analysis of the Real Interest Rate under Regime Shifts", Review of Economics and Statistics 78, 111-125. 
Goetzmann, William N., 1993, "The Single Family Home in the Investment Portfolio", Journal of Real Estate Finance and Economics 6, 201-222.

Gottschalk, Peter, and Robert Moffitt, 1994, "The Growth of Earnings Instability in the U.S. Labor Market", Brookings Papers on Economic Activity 2, 217-272.

Gourinchas, Pierre-Olivier and Jonathan Parker, 2002, "Consumption Over the Life Cycle", Econometrica 70, 47-89.

Gray, Stephen F., 1996, "Modelling the Conditional Distribution of Interest Rates as a Regime-Switching Process", Journal of Financial Economics 42, 27-62.

Hu, Xiaoqing, 2001, "Portfolio Choices for Home Owners", unpublished paper, Northwestern University.

Irwin, Robert, 1996, Tips and Traps When Buying a Home, 2nd ed., McGraw-Hill, New York, NY.

Irwin, Robert, 1999, Tips and Traps When Mortgage Hunting, 2nd ed., McGraw-Hill, New York, NY.

Kearl, J.R., 1979, "Inflation, Mortgages, and Housing", Journal of Political Economy $87,1115-1138$.

LeRoy, Stephen F., 1996, "Mortgage Valuation Under Optimal Prepayment," Review of Financial Studies 9, 817-844.

MaCurdy, Thomas, 1982, "The Use of Time Series Processes to Model The Error Structure of Earnings in a Longitudinal Data Analysis", Journal of Econometrics $18,83-114$.

Merton, Robert C., 1973, "An Intertemporal Capital Asset Pricing Model", Econometrica 41, 867-887.

Mishkin, Frederic S., 1990, "What Does the Term Structure Tell Us About Future Inflation?", Journal of Monetary Economics 25, 77-95.

Orman, Suze, 1999, The Courage to Be Rich, Riverhead Books, New York, NY.

Ortalo-Magné, François and Sven Rady, 2001, "Housing Market Dynamics: On the Contribution of Income Shocks and Credit Constraints," unpublished paper, LSE. 
Poterba, James M., 1991, "House Price Dynamics: The Role of Tax Policy and Demography," Brookings Papers on Economic Activity 2, 143-183.

Roll, Richard, 2003, "Empirical TIPs", unpublished paper, Anderson Graduate School of Management, UCLA.

Rothberg, James P., Frank E. Nothaft, and Stuart A. Gabriel, 1989, "On the Determinants of Yield Spreads Between Mortgage Pass-Through and Treasury Securities", Journal of Real Estate Finance and Economics 2, 301-315.

Schwartz, Eduardo S. and Walter N. Torous, 1989, "Prepayment and the Valuation of Mortgage-Backed Securities", Journal of Finance 44, 375-392.

Shiller, Robert J., 1998, Macro Markets: Creating Institutions for Managing Society's Largest Economic Risks, Oxford University Press, New York, NY.

Shiller, Robert J. and Allan Weiss, 1999, "Home Equity Insurance", Journal of Real Estate Finance and Economics 19, 21-47.

Shilling, J.D., U. S. Dhillon, and C.F. Sirmans, 1987, "Choosing Between Fixed and Adjustable Rate Mortgages," Journal of Money, Credit, and Banking 19, 260-267.

Sinai, Todd and Nicholas Souleles, 2003, "Owner-Occupied Housing as a Hedge Against Rent Risk", unpublished paper, Wharton School, University of Pennsylvania.

Skinner, Jonathan, 1994, "Housing and Saving in the United States", in Yukio Noguchi and James M. Poterba eds. Housing Markets in the United States and Japan, University of Chicago Press, Chicago, IL, 191-213.

Stanton, Richard, 1995, "Rational Prepayment and the Valuation of MortgageBacked Securities", Review of Financial Studies 8, 677-708.

Stanton, Richard and Nancy Wallace, 1998, "Mortgage Choice: What's the Point?", Real Estate Economics 26, 173-205.

Stanton, Richard and Nancy Wallace, 1999, "Anatomy of an ARM: The InterestRate Risk of Adjustable-Rate Mortgages", Journal of Real Estate Finance and Economics 19, 49-67. 
Statman, Meir, 1982, "Fixed Rate or Index-Linked Mortgages from the Borrower's Point of View: A Note", Journal of Financial and Quantitative Analysis 17, 451-457.

Steinmetz, Thomas C., 2002, The Mortgage Kit, 5th ed., Dearborn Trade Publishing, Chicago, IL.

Storesletten, Kjetil, Chris I. Telmer, and Amir Yaron, 2003, "Consumption and Risk Sharing over the Life Cycle", forthcoming Journal of Monetary Economics.

Tauchen, George and R. Hussey, 1991, "Quadrature-Based Methods for Obtaining Approximate Solutions to Nonlinear Asset Pricing Models", Econometrica 59, 371-396.

Tracy, Joseph and Henry Schneider, 2001, "Stocks in the Household Portfolio: A Look Back at the 1990s", Current Issues in Economics and Finance 7(4), 1-6, Federal Reserve Bank of New York.

Tracy, Joseph, Henry Schneider, and Sewin Chan, 1999, "Are Stocks Overtaking Real Estate in Household Portfolios?", Current Issues in Economics and Finance 5(5), 1-6, Federal Reserve Bank of New York.

Tyson, Eric and Ray Brown, 2000, Mortgages for Dummies, Hungry Minds Inc., New York, NY.

Woodward, Susan, 2001, "Rechartering Freddie and Fannie: The Policy Issues", unpublished paper, Sand Hill Econometrics.

Yao, Rui and Harold H. Zhang, 2001, "Optimal Consumption and Portfolio Choices with Risky Housing and Stochastic Labor Income", unpublished paper, University of North Carolina at Chapel Hill.

Zeldes, Stephen, 1989, "Optimal Consumption with Stochastic Income: Deviations from Certainty Equivalence", Quarterly Journal of Economics 104, 275-298. 


\section{Table 1: Calibrated and estimated parameters}

\begin{tabular}{lcc}
\hline Description & Parameter & Value \\
\hline Risk aversion & $\gamma$ & 3 \\
Discount factor & $\beta$ & .98 \\
House size (\$ thousands) & $H$ & $125,187.5$ \\
Downpayment ratio & $\lambda$ & .20 \\
Tax rate & $\tau$ & .20 \\
\hline Mean log inflation & $\mu$ & .046 \\
S.d. of log inflation & $\sigma\left(\pi_{1 t}\right)$ & .039 \\
Autoregression parameter & $\phi$ & .754 \\
Mean log real yield & $\bar{r}$ & .020 \\
S.d. of real log yield & $\sigma\left(r_{1 t}\right)$ & .022 \\
\hline Nominal FRM premium & $\theta^{F}$ & .018 \\
Term premium & $\xi$ & .010 \\
Refinancing cost (\$ thousands) & $\rho$ & $1, \infty$ \\
ARM premium & $\theta^{A}$ & .017 \\
Second loan premium & $\theta^{B}$ & $\infty$ \\
Rental premium & $\theta^{Z}$ & .030 \\
\hline Mean real house price growth & $\exp \left(g+\sigma_{\delta}^{2} / 2\right)$ & .016 \\
S.d. of log real house price growth & $\sigma_{\delta}$ & .115 \\
\hline S.d. of transitory income shocks & $\sigma_{\omega}$ & $.141, .248$ \\
S.d. of persistent income shocks & $\sigma_{\eta}$ & .020 \\
Corr. trans. income and inflation shocks & $\varphi$ & .000 \\
\hline
\end{tabular}

All parameters are in annual terms. The interest rate measure is the one-year Treasury bond rate from 1962 to 1999. The income and house price data are from the PSID from 1970 through 1992. Families that were part of the Survey of Economic Opportunities were dropped from the sample. Labor income in each year is defined as total reported labor income plus unemployment compensation, workers compensation, social security, supplemental social security, other welfare, child support, and total transfers, all this for both head of household and if present his spouse. Labor income and reported house prices were deflated using the Consumer Price Index. 
Table 2: Consumption growth with nominal mortgages

\begin{tabular}{lcccccc}
\hline & \multicolumn{3}{c}{$\overline{\Delta c_{t}}$} & \multicolumn{5}{c}{$\sigma\left(\Delta c_{t}\right)$} \\
Refinancing & ARM & $\begin{array}{c}\text { FRM } \\
\text { Yes }\end{array}$ & $\begin{array}{c}\text { FRM } \\
\text { No }\end{array}$ & ARM & $\begin{array}{c}\text { FRM } \\
\text { Yes }\end{array}$ & $\begin{array}{c}\text { FRM } \\
\text { No }\end{array}$ \\
\hline $\bar{H}=125.0, \sigma_{\omega}=.141$ & 1.5 & 1.5 & 1.5 & 12.1 & 13.6 & 13.7 \\
$\bar{H}=125.0, \sigma_{\omega}=.248$ & 2.2 & 2.2 & 2.2 & 17.1 & 18.6 & 18.7 \\
$\bar{H}=187.5, \sigma_{\omega}=.141$ & 2.0 & 2.0 & 1.9 & 13.9 & 15.6 & 15.9 \\
$\bar{H}=187.5, \sigma_{\omega}=.248$ & 2.8 & 2.8 & 2.8 & 19.4 & 20.7 & 20.9 \\
\hline & \multicolumn{5}{c}{ Panel B: Single } \\
$\bar{H}=125.0, \sigma_{\omega}=.141$ & 1.9 & 1.9 & 1.8 & 13.5 & 15.2 & 15.5 \\
$\bar{H}=125.0, \sigma_{\omega}=.248$ & 2.8 & 2.8 & 2.8 & 17.6 & 18.8 & 19.0 \\
$\bar{H}=187.5, \sigma_{\omega}=.141$ & 3.0 & 2.9 & 2.8 & 17.9 & 19.5 & 20.0 \\
$\bar{H}=187.5, \sigma_{\omega}=.248$ & 4.1 & 4.1 & 4.1 & 22.4 & 24.2 & 24.7 \\
\hline
\end{tabular}

This table shows average annual consumption growth, for goods other than housing, the standard deviation of annual consumption growth under different mortgage contracts and for different parameter configurations. The data are obtained by simulating the model in section 2. Annual average consumption growth and the standard deviation of annual consumption growth are obtained by dividing the two-year values by two and square root of two, respectively. The FRM contract can allow for refinancing at a $\$ 1,000$ cost, or can prohibit refinancing. Panel A shows the results for households composed of a couple, and Panel B shows the results for households composed of a single individual. 
Table 3: Welfare analysis of nominal mortgages

\begin{tabular}{lccc}
\hline & \multicolumn{2}{c}{ FRM } & Refinancing \\
Refinancing & Yes & No & Option \\
\hline $\bar{H}=125.0, \sigma_{\omega}=.141$ & -6.34 & -6.84 & 0.50 \\
$\bar{H}=125.0, \sigma_{\omega}=.248$ & -5.72 & -6.32 & 0.59 \\
$\bar{H}=187.5, \sigma_{\omega}=.141$ & -5.96 & -6.79 & 0.83 \\
$\bar{H}=187.5, \sigma_{\omega}=.248$ & -5.40 & -6.31 & 0.91 \\
\hline$\overline{4}$ Panel B: Single \\
$\bar{H}=125.0, \sigma_{\omega}=.141$ & -5.77 & -6.51 & 0.74 \\
$\bar{H}=125.0, \sigma_{\omega}=.248$ & -5.43 & -6.20 & 0.76 \\
$\bar{H}=187.5, \sigma_{\omega}=.141$ & -5.71 & -7.29 & 1.58 \\
$\bar{H}=187.5, \sigma_{\omega}=.248$ & -1.03 & -3.16 & 2.13 \\
\hline
\end{tabular}

This table shows the mean welfare gain delivered by a nominal FRM, with and without refinancing at a $\$ 1,000$ cost, relative to an ARM. The data are obtained by simulating the model in section 2 . Welfare is reported in the form of standard consumption-equivalent variations. We weight the different states by the ergodic or steady-state distribution. For each mortgage contract we compute the constant consumption stream that makes the household as well off in expected utility terms. Utility losses are then obtained by measuring the change in this equivalent consumption stream across mortgage contracts. Panel A shows the results for households composed of a couple, and Panel B shows the results for households composed of a single individual. The last column shows the value of the option to refinance obtained as the welfare difference for the refinancing and no refinancing versions of the FRM. 
Table 4: Consumption growth with inflation-indexed mortgages

\begin{tabular}{lcccccc}
\hline & \multicolumn{3}{c}{$\overline{\Delta c_{t}}$} \\
& ARM & $\begin{array}{c}\text { Inflation-indexed FRM } \\
\text { Constant }\end{array}$ & ARM & \multicolumn{2}{c}{$\sigma\left(\Delta c_{t}\right)$} \\
Declining & & Inflation-indexed FRM \\
Constant & Declining \\
\hline $\bar{H}=125.0, \sigma_{\omega}=.141$ & 1.5 & 0.8 & 1.5 & 12.1 & 11.7 & 12.0 \\
$\bar{H}=125.0, \sigma_{\omega}=.248$ & 2.2 & 1.5 & 2.1 & 17.1 & 17.4 & 18.2 \\
$\bar{H}=187.5, \sigma_{\omega}=.141$ & 2.0 & 0.8 & 1.9 & 13.9 & 12.9 & 14.4 \\
$\bar{H}=187.5, \sigma_{\omega}=.248$ & 2.8 & 1.6 & 2.6 & 19.4 & 18.5 & 19.1 \\
\hline & & \multicolumn{5}{c}{ Panel A: Couple } \\
$\bar{H}=125.0, \sigma_{\omega}=.141$ & 1.9 & 0.8 & 1.8 & 13.5 & 12.5 & 13.5 \\
$\bar{H}=125.0, \sigma_{\omega}=.248$ & 2.8 & 1.7 & 2.7 & 17.6 & 15.9 & 17.6 \\
$\bar{H}=187.5, \sigma_{\omega}=.141$ & 2.9 & 0.8 & 2.6 & 17.9 & 14.7 & 17.5 \\
$\bar{H}=187.5, \sigma_{\omega}=.248$ & 4.1 & 1.9 & 3.7 & 22.4 & 18.4 & 22.2 \\
\hline
\end{tabular}

This table shows average annual consumption growth, for goods other than housing, the standard deviation of annual consumption growth under different mortgage contracts and for different parameter configurations. A standard ARM contract is compared with two alternative inflation-indexed FRMs, one with constant real payments and one with real payments that decline at the average rate of inflation. The data are obtained by simulating the model in sections 2 and 4 . Annual average consumption growth and the standard deviation of annual consumption growth are obtained by dividing the two-year values by two and square root of two, respectively. Panel A shows the results for households composed of a couple, and Panel B shows the results for households composed of a single individual. 
Table 5: Welfare analysis of inflation-indexed mortgages

\begin{tabular}{|c|c|c|c|}
\hline & \multirow[t]{2}{*}{ Nominal FRM } & \multicolumn{2}{|c|}{ Inflation-indexed FRM } \\
\hline & & Constant & Declining \\
\hline & \multicolumn{3}{|c|}{ Panel A: Couple } \\
\hline $\bar{H}=125.0, \sigma_{\omega}=.141$ & -6.34 & 1.40 & 0.12 \\
\hline $\bar{H}=125.0, \sigma_{\omega}=.248$ & -5.72 & 2.22 & 0.24 \\
\hline $\bar{H}=187.5, \sigma_{\omega}=.141$ & -5.96 & 3.95 & 0.91 \\
\hline $\bar{H}=187.5, \sigma_{\omega}=.248$ & -5.40 & 7.40 & 2.39 \\
\hline & \multicolumn{3}{|c|}{ Panel B: Single } \\
\hline $\bar{H}=125.0, \sigma_{\omega}=.141$ & -5.77 & 3.49 & 0.67 \\
\hline $\bar{H}=125.0, \sigma_{\omega}=.248$ & -5.43 & 6.69 & 1.69 \\
\hline$\overline{\bar{H}}=187.5, \sigma_{\omega}=.141$ & -5.71 & 15.86 & 7.30 \\
\hline $\bar{H}=187.5, \sigma_{\omega}=.248$ & -1.03 & 36.42 & 16.05 \\
\hline
\end{tabular}

This table shows the mean welfare gain delivered by a nominal FRM and by an inflation-indexed FRM, with constant real payments and with real payments which diminish at the average rate of inflation, relative to an ARM. The data are obtained by simulating the model in sections 2 and 4 . Welfare is reported in the form of standard consumption-equivalent variations. We weight the different states by the ergodic or steady-state distribution. For each mortgage contract we compute the constant consumption stream that makes the household as well off in expected utility terms. Utility losses are then obtained by measuring the change in this equivalent consumption stream across mortgage contracts. Panel A shows the results for households composed of a couple, and Panel B shows the results for households composed of a single individual. 


\section{Table 6: Welfare analysis under alternative parameterizations}

\begin{tabular}{lccc}
\hline & Nominal FRM & \multicolumn{2}{c}{ Inflation-indexed FRM } \\
& & Constant & Declining \\
\hline 1. Benchmark & -5.96 & 3.95 & 0.91 \\
2. Correlated income and inflation $(\varphi=-1.00)$ & -2.87 & 5.16 & 1.81 \\
3. 1983-1999 parameters & -6.94 & 1.01 & 0.02 \\
4. Lower second loan premium $\left(\theta^{B}=1 \%\right)$ & -6.40 & 1.57 & 0.97 \\
5. Higher moving probability $(p=10 \%)$ & -6.60 & 8.94 & 0.86 \\
6. Lower rental premium $\left(\theta^{Z}=2 \%\right)$ & -6.08 & 3.83 & 0.85 \\
7. Higher rental premium $\left(\theta^{Z}=4 \%\right)$ & -5.79 & 4.14 & 1.09 \\
8. Higher time discount rate $(\beta=0.90)$ & -6.49 & 12.46 & 1.46 \\
9. Higher risk aversion $(\gamma=5)$ & -1.33 & 8.12 & 4.58 \\
10. More volatile permanent income $\left(\sigma_{\eta}=5 \%\right)$ & -5.11 & 2.17 & 0.90 \\
11. Hybrid ARM contract & -6.75 & 3.09 & 0.07 \\
12. Correlated income and real rates & -5.90 & 4.02 & 0.97 \\
13. Term premium in the real term structure & -5.96 & -1.34 & -3.72 \\
\hline
\end{tabular}

This table shows the mean welfare gain delivered by a nominal FRM and by an inflation-indexed FRM, with constant real payments and with real payments which diminish at the average rate of inflation, relative to an ARM for different parameterizations. The data are obtained by simulating the model in sections 2 and 4 . The first row shows the results for our benchmark case, which is a couple needing to finance a house of $\$ 187,500$ and facing labor income risk $\sigma_{\omega}=.141$. The second shows the results for a correlation between transitory labor income and inflation shocks equal to minus one. The third row shows the results when the parameters of the inflation and real interest rate processes are calibrated using data for the 1983-1999 period. The annual parameters are: $\mu=.034, \sigma\left(\pi_{1 t}\right)=.012, \phi=.412, \bar{r}=.031$, and $\sigma\left(r_{1 t}\right)=.016$. In the fourth row we allow homeowners to take out second loans if they have positive home equity, with a second loan premium of $1 \%$. The fifth row shows the results for a probability of moving equal to $10 \%$. The sixth and seventh rows show the results for a lower and a higher rental premium in case of default. The eighth row shows the results for a higher time discount rate, corresponding to a lower time discount factor of 0.90. The ninth row shows the results for a higher coefficient of relative risk aversion. The tenth row shows the results for a higher standard deviation for 
permanent income shocks. The eleventh row shows the results for a hybrid ARM characterized by a $2 \%$ cap per year and a $6 \%$ lifetime cap. The twelfth row shows the results for a correlation of income growth and real interest rate shocks equal to -0.2 . The last row shows the results assuming that the term premium of $1 \%$ is in the real term structure rather than the nominal term structure. 
Figure 1: Portion of Household Assets in Corporate Equity and Real Estate by Wealth Percentile, 1989 - 1998

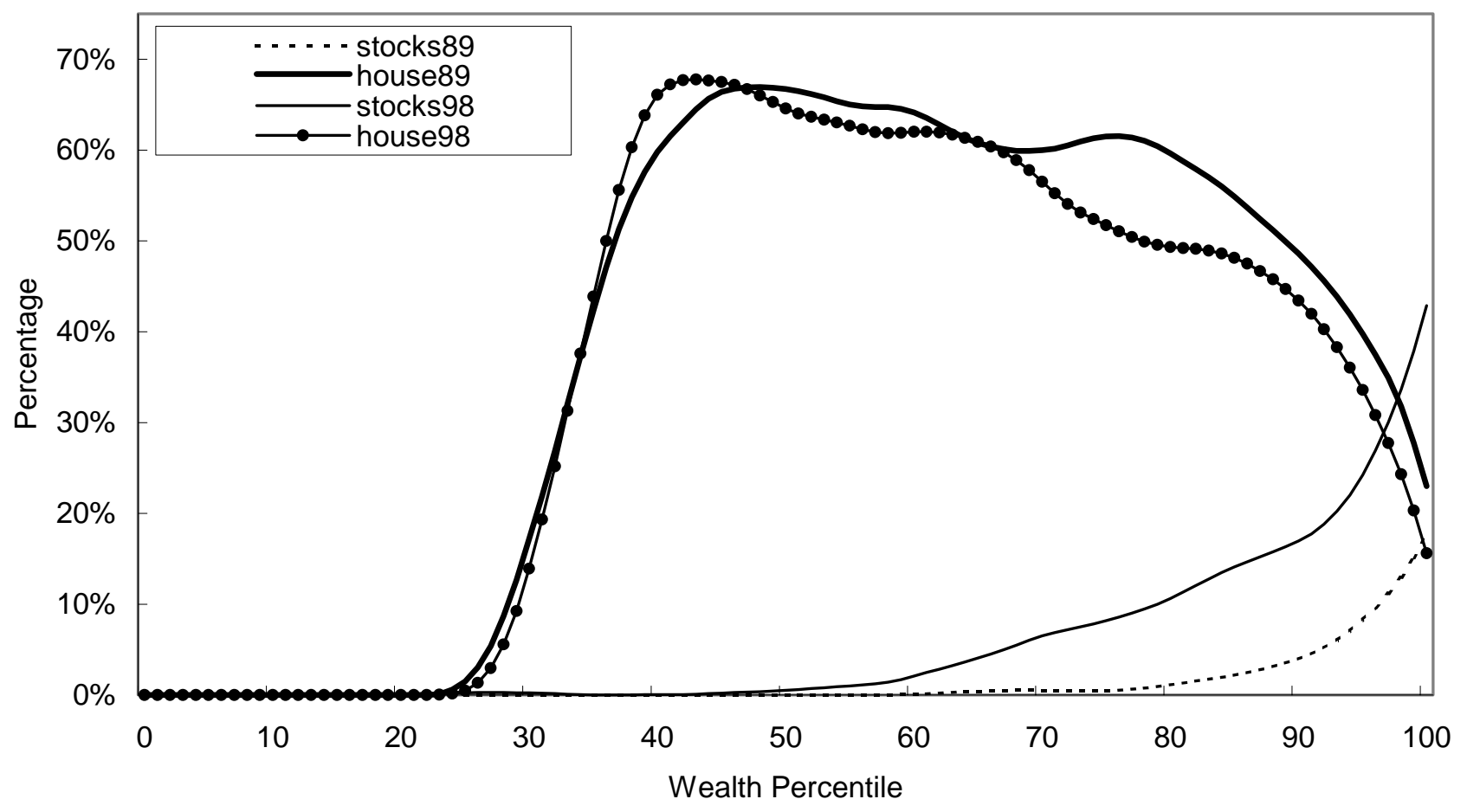

Figure 1: Portion of Household Assets in Corporate Equity and Real Estate by Wealth Percentile, 1989 and 1998. The data are from the 1989 and 1998 Survey of Consumer Finances. We would like to thank Joe Tracy for kindly providing us the data for this figure. 
Figure 2: Percentage of conventional single-family mortgages originated by major lenders with fixed-rates

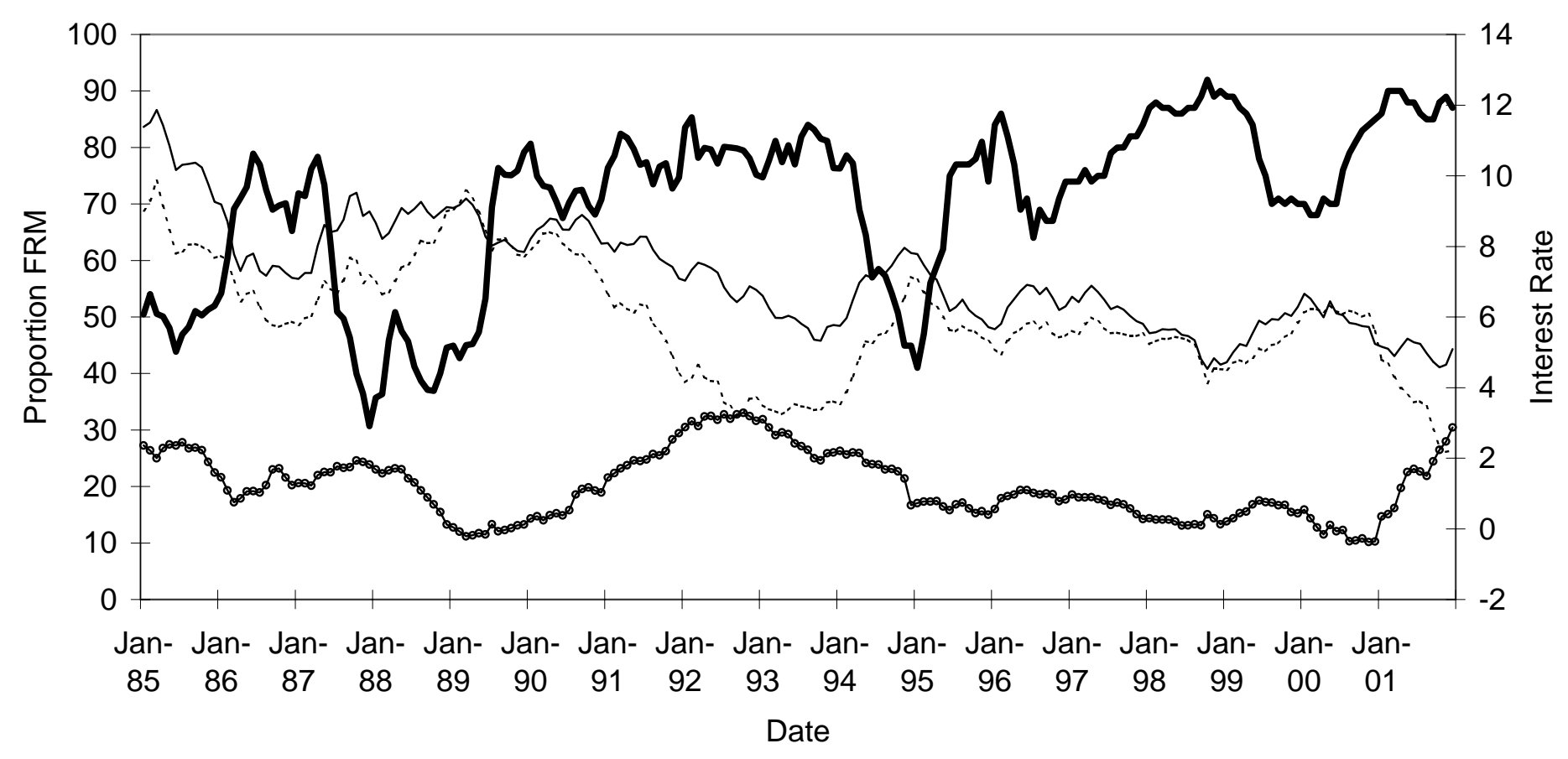

-Proportion FRM $\cdots \cdots \cdot 1$ Year Treasury Rate -10 Year Treasury Rate $\longrightarrow$ Yield Spread

Figure 2: FRM share. This figure plots the percentage of conventional single-family mortgages originated by major lenders with fixed rates. The data is from the monthly interest rate survey of the Federal Housing Finance Board from January 1985 to December 2001. This figure also plots the 1-year Treasury rate, the 10-year Treasury rate and the yield spread between 10-year and 1-year interest rates. 
Figure 3: Labor income profile.

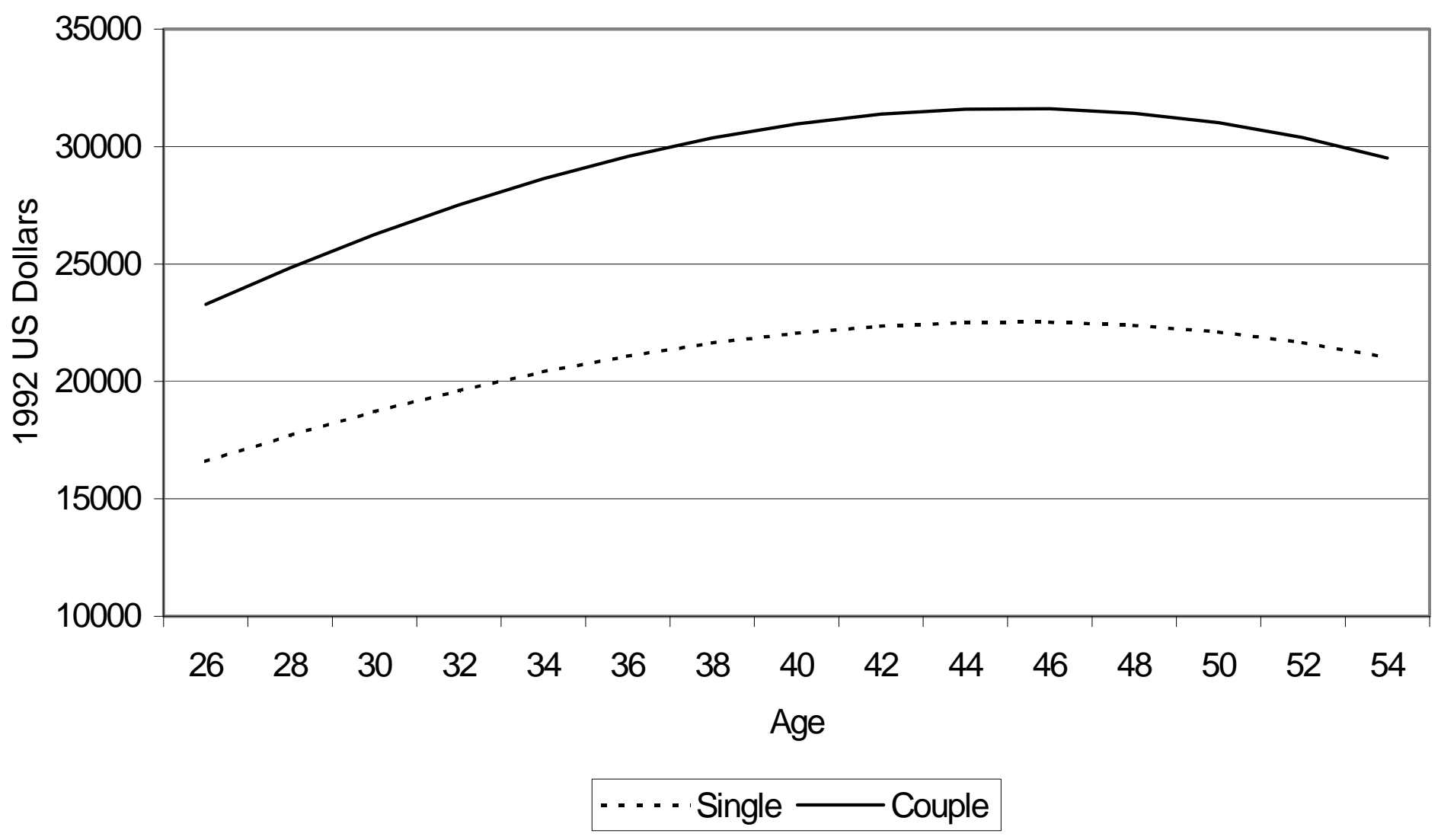

Figure 3: Labor income profile. This figure plots a fitted third-order polynomial to the estimated age dummies for households composed of single individual and for a couple. The data are from the PSID for the years 1970 through 1992. We use a broad definition of labor income, defined as total reported labor income plus unemployment compensation, workers compensation, social security, supplemental social security, other welfare, child support and total transfers (mainly help from relatives), all this for both head of household and if present his spouse. Observations which still reported zero for this broad income category were dropped. In order to obtain a random sample we dropped families that are part of the Survey of Economic Opportunities subsample. 
Figure 4: Benchmark Utility Distribution

Panel A: Couple

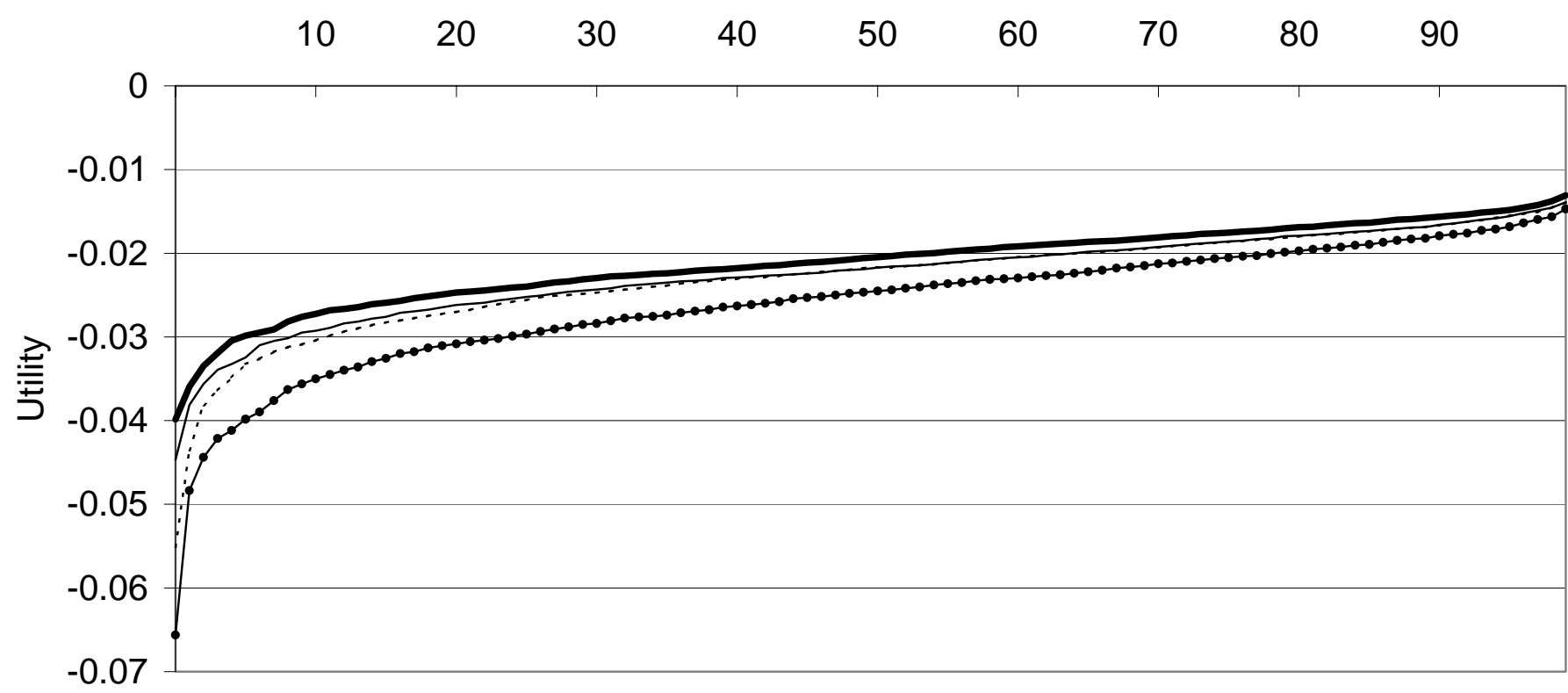

Percentile

$\cdots$ ARM $\rightarrow$ - FRM — Indexed - Declining —Indexed - Fixed

Panel B: Single

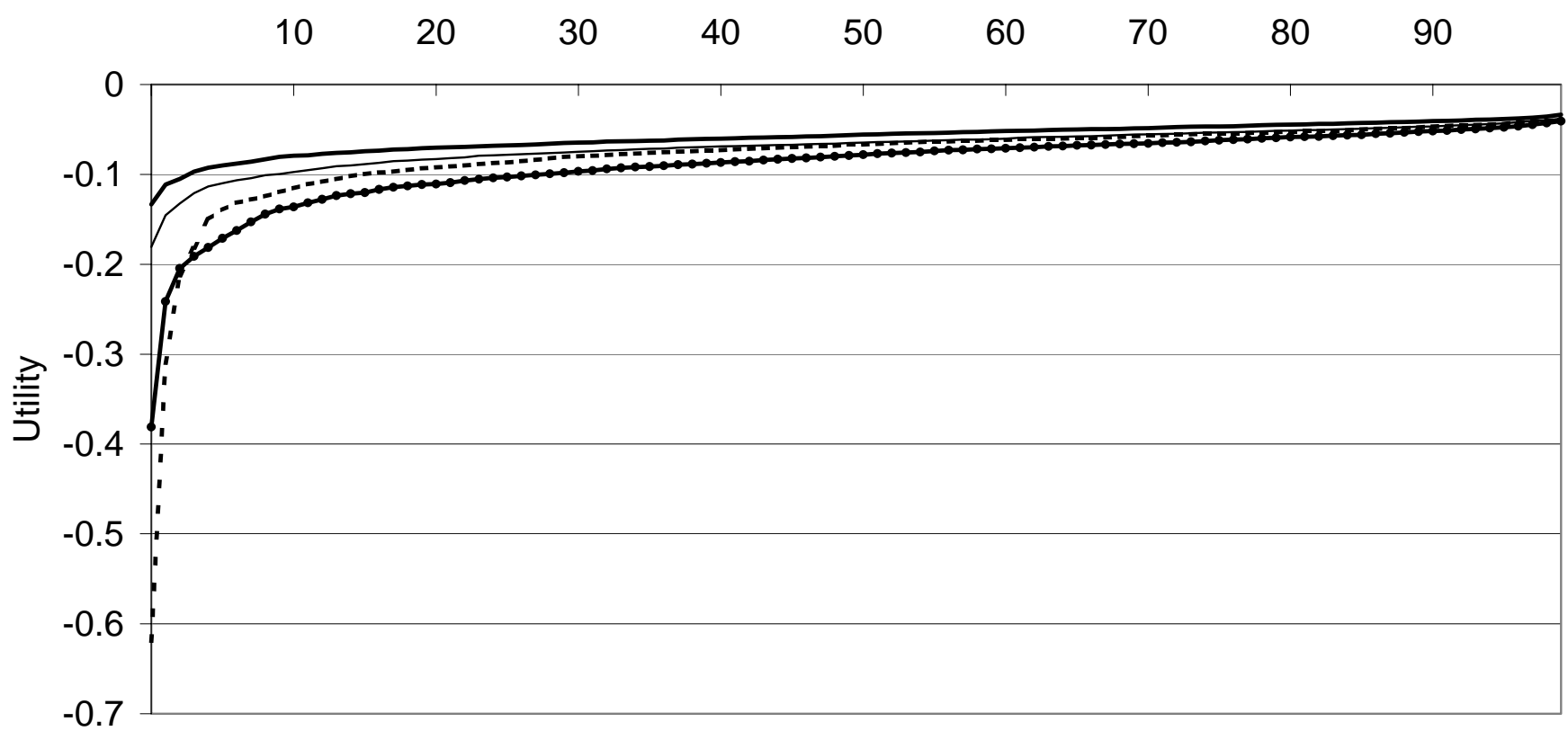

Percentile

- - ARM $\rightarrow$ FRM — Indexed - Declining —Indexed - Fixed 
Figure 4: Benchmark utility distribution. This figure shows various percentiles of the distribution of realized utility when we simulate the model for 1,000 households. Panel shows the results for households composed of a couple and panel B for households composed of a single individual. The parameters of the model are given in Table 1, with the size of the house that needs to be financed equal to $\$ 187,500$. The figure illustrates utility for an ARM and a nominal FRM with refinancing cost of $\$ 1,000$, an inflationindexed FRM whose real payments which diminish at the average rate of inflation, and an inflation-indexed FRM with fixed real mortgage payments. 
Figure 5: Cumulative default and mortgage refinancing for a single individual

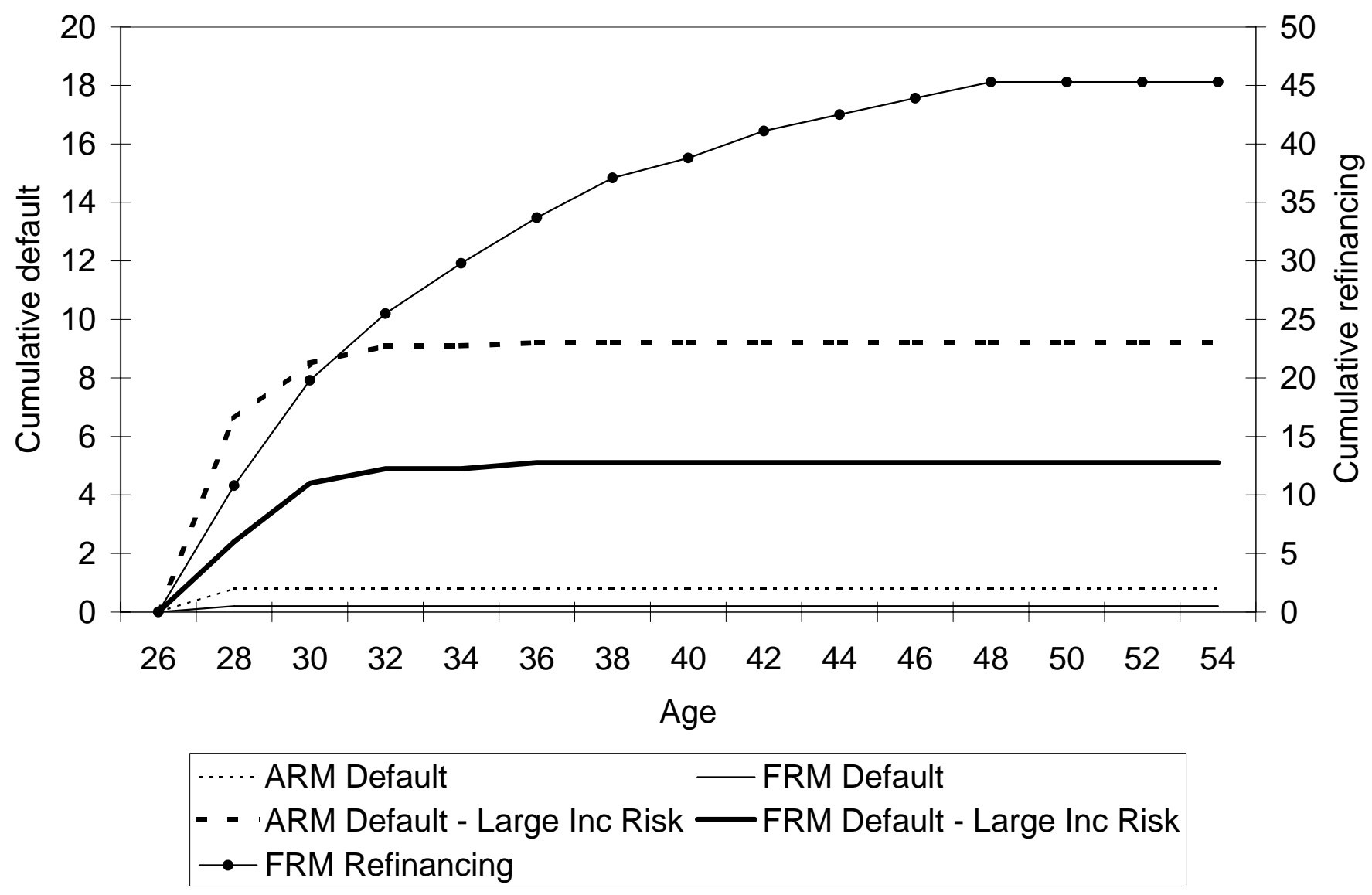

Figure 5: Cumulative default and mortgage refinancing. This figure shows the cumulative proportion of investors who choose to default under the FRM and ARM contracts for a household composed of a single individual and for two levels of labor income risk. The parameters of the model are given in Table 1, with with the size of the house that needs to be financed equal to $\$ 187,500$. The figure also shows the cumulative proportion of households composed of a single individual who refinance the FRM contract for low income risk. 